\title{
THE NATURE OF SEISMICITY PATTERNS BEFORE LARGE EARTHQUAKES
}

Hiroo Kanamori

\author{
Seismological Laboratory
}

California Institute of Technology, Pasadena, California 91125

Abstract. Various seismicity patterns before major earthquakes have been reported in the literature. They include foreshocks (broad sense), preseismic quiescence, precursory swarms, and doughnut patterns. Although many earthquakes are preceded by all, or some, of these patterns, their detail differ significantly from event to event. In order to examine the details of seismicity patterns on as uniform a basis as possible, we made space-time plots of seismicity for many large earthquakes by using the NOAA and JMA catalogs. Among various seismicity patterns, preseismic quiescence appears most common, the case for the 1978 Oaxaca earthquake being the prominent.

Although the nature of other patterns varies from event to event, a common physical mechanism may be responsible for these patterns; details of the pattern are probably controlled by the tectonic environment (fault geometry, strain rate) and the heterogeneity of the fault plane. Here a simple asperity model is introduced to explain these seismicity patterns. In this model, a fault plane with an asperity is divided into a number of subfaults. The subfaults within the asperity are, on the average, stronger than those in the surrounding weak zone. As the tectonic stress increases, the subfaults in the weak zone break in the form of background small earthquakes. If the frequency distribution of the strength of the subfaults has a sharp peak, a precursory swarm occurs. By this time, most of the subfaults in the weak zone are broken and the fault plane becomes seismically quiet. As the tectonic stress increases further, eventually the asperity breaks and sympathetic displacement occurs on the entire fault zone in the form of the main shock. Foreshocks do or do not occur depending upon the distribution of the strength of the subfaults within the asperity. Since the spatio-temporal change in the stress on the fault plane is most likely to dictate the change in seismicity patterns, detailed analysis of seismicity patterns would provide a most direct clue to the state of stress in the fault zone. However, because of the large variation from event to event, seismicity pattern alone is not a definitive tool for earth- quake prediction; measurements of other physical parameters such as the spectra, the mechanism and the wave forms of the background events should be made concurrent1y.

\section{Introduction}

Spatio-temporal variations of seismicity before major earthquakes have been studied by many irvestigators in an attempt to understand the physical mechanism of earthquakes and to use them as a tool for earthquake prediction. In this paper, we review the recent progress in this field, add some new data, and propose a simple model which facilitates the understanding of the nature of these seismicity patterns.

Since these patterns lave not been defined unarbiguously, we first discuss some representative patterns by using a schematic diagram shown by Figure 1. This figure includes, following Mogi (1976), the pattern of foreshocks, precursory swarms, precursory quiescence and doughuut patterns.

\section{Foreshocks}

Although there is no widely accepted definition of foreshocks, some earthquakes (e.g., 1974 Haicheng, China earthquake; 1963 Kuril€ Islands earthquake) were preceded by a very remarkable short-term increase in the number of small events in the epicentral area so that little ambiguity exists in calling them the foreshocks. In other cases, however, ambiguity arises because of either too small number of events, too spreadout time interval, or both. Yet these events may be causally and/or physically related to the mainshock, and may be called the foreshocks.

Sometimes small events which preceded a mainshock and occurred in, or in the neighborhood of, the mainshock rupture zone are called preshocks. In this paper, we will use the term foreshocks in a rather loose sense of the word to include both "obvious" foreshocks and preshocks.

According to Jones and Molnar (1976), about 44\% of large shallow earthquakes in the world were 


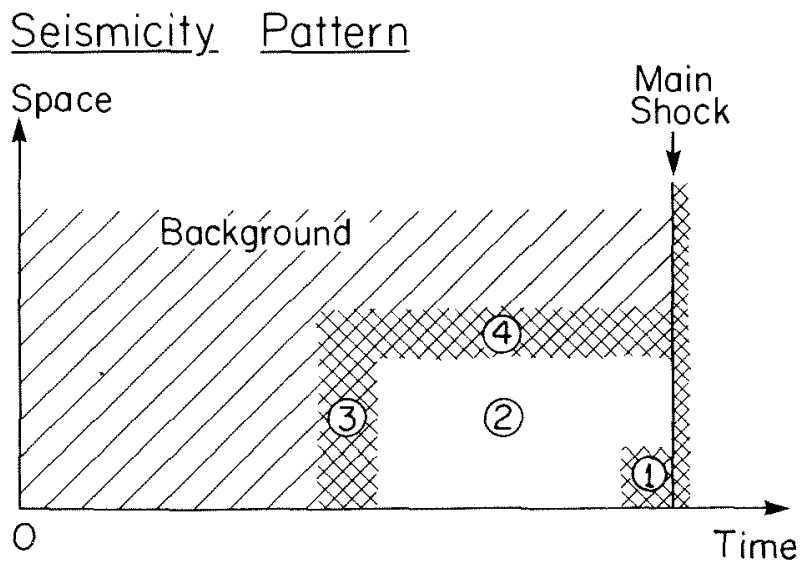

\section{Elementary Patterns}

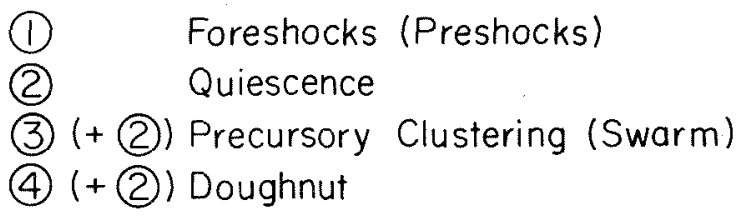

Fig. 1. Schematic space-time diagram showing various seismicity patterns. (Modified from $\operatorname{Mog} i, 1977$ ).

preceded by foreshocks of their definition. A very useful summary of foreshock activity in Japan can be found in Mogi (1963). Among the best documented foreshock sequences are those of the 1974 Haicheng, China earthquake (Wu et al., 1978), the 1978 Oaxaca, Mexico earthquake (Ponce, et a1., 1977-1978) and the 1963 Kurile Islands eqrthquake (Santô, 1964).

Occasionally, a very tight clustering of activity occurs before the mainshock. Mogi (1968b) and Kelleher and Savino (1975) demonstrated that seismic activity prior to a great earthquake tends to cluster around the epicenter of the eventual mainshock. More recent1y, Ishida and Kanamori (1978) and Fuis and Lindh (1979) found a very tight clustering of activity before the 1971 San Fernando, California and the 1975 Galway Lake, California earthquakes, respectively. Engdah1 and Kisslinger (1977) found a clustering of small events before a magnitude 5 earthquake in the Central Aleutians. Although these events are not usually called typical foreshocks, they can be considered to be foreshocks in a broader sense, or preshocks.

\section{Gap}

Imamura (1928) investigated historical data on large earthquakes in southwest Japan (TokaidoNankaido region), and found that large earthquakes in this region had occurred repeatedly at approximately the same location with a repeat time of about 100 to 150 years. He puinted out that the area southeast of the Kii peninsula and Shikoku island had not experienced a large earthquake for 70 years, and suggested that a large earthquake was imminent there. The Tonankai $\left(k_{G}=8.0\right)$ and the Nankaido $\left(M_{\mathrm{S}}=8.2\right)$ earthquakes indeed occurred there in 1944 and 1946 respectively. Fedotov (1965) and Mogi. (1968a) studied seismicity in the Kamchatka, Kurile and Japan regions and identified several zones which had not experienced a large earthquake for a long time. These zones were considered to be candidate sites of major earthquakes in the future. In fact, several major earthquakes including the 1968 Tokachi-oki, Japan earthquake $\left(M_{W}=8.2\right)$ occurred in these zones subsequent1y. These results were furhter extended to the concept of seismic gaps, and have been used more globally by many investigators (Kelleher, 1970; Utsu, 1970; Kelleher et a1., 1973; Sykes, 1971; Ohtake et a1., 1977). Kelleher and Savino (1975) demonstrated that gaps in seismicity for great earthquakes are also gaps for smaller magnitude activity and such gaps commonly persist until the time of the mainshock. A very comprehensive review can be found in McCann et al. (1980). Usually these seismic gaps refer to a spatial gap of seismic activity, particularly of large earthquakes.

\section{Quiescence}

Inouye (1965) found that seismicity in the epicentral area of several large earthquakes in Japan (e.g., 1952 Tokachi-oki and 1964 Niigata earthquakes) became very low before the mainshock. This quiescence was followed by increased activity for several years before the mainshock. Mogi (1968a) showed that before several large earthquakes (e.g., 1944 Tonankai and the 1946 Nankaido earthquakes), the focal region became very calm. These studies suggested that seismic activity in the eventual rupture zone of a large earthquake decreases more or less abruptly sometime before the mainshock. In this regard this pattern may be called a temporal gap. Perhaps the most pronounced of the temporal gaps is the one before the 1978 Oaxaca, Mexico earthquake $\left(M_{W}=7.6\right)$ reported by Ohtake et a1. (1977). Mogi (1979) called the spatial gap and the temporal gap, the gap of the 1 st and 2 nd kind respectively. In any case, a preseismic quiescence of seismic activity in the epicentral area of a large earthquake appears very common to many large earthquakes.

\section{Precursory Swarm}

McNally (1977) found that distinct clusters of sma11 earthquakes occurred in the near-source region of several moderate size earthquakes in Central California 2 to 10 years before the mainshock. Sekiya (1977) and Ohtake (1976) reported that anomalous seismic activity occurred about 10 years before the 1974 Izu-Hanto-oki earthquake in the epicentral area which had generally been quiet before the earthquake. Sekiya (1977) 
reported further examples for ahout ten other Japanese earthquakes. Evison $(1977 \mathrm{a}, \mathrm{b})$ found such precursory activities before the 1968 Borrego Mountain, California earthquake and several earthquakes in New Zealand. Evison considered that a burst of seismic activity marks the start of a precursory sequence, and called it the precursory earthquake swarm. Brady (1976) found a clustering of seismic activity before the 1971 San Fernando, California earthquake and interpreted it as a "primary inclusion zone" of the impending failure.

\section{Doughnut Pattern}

Mogi (1969) found that before several large earthquakes in Japan, the region surrounding the focal region became very active, while the focal region was quiet at the same time. This pattern is often called a doughnut pattern. A similar doughnut pattern has been reported for a magnitude 6 earthquake in Kyushu, Japan by Mitsunami and Kubotera (1977) and for a magnitude 6.1 earthquake in the Shimane prefecture, Japan by Yamashina and Inoue (1979).

For many earthquakes, these elementary seismicity patterns described above appear either by itself or as combinations so that the actual pattern often becomes very complex. Furthermore, identification and classification of the patterns depend upon the catalog used for the study, the magnitude threshold, the time period, the depth range, and the judgement of the investigators, so that entirely different patterns have of ten been identified for the same event. Because of this ambiguity, the reported seismicity pattern should not be regarded as a unique feature of the earthquake, but should rather be regarded as a manifestation of the physical process leading to an earthquake.

In genera1, two approaches are possible in using seismicity patterns for earthquake prediction. The first is represented by the works of Keilis Borok et al. (e.g., 1980), Wyss et al. (1978) and Habermann (1980). In this method, various seismicity patterns are treated as rigorously as possible in a statistical framework to establish an empirical algorithm for earthquake prediction. Essential to this approach are the uniformity of earthquake catalogs and rigorous definition of the seismicity patterns.

In the second approach, various seismicity patterns are used as a clue to the physical. mechanism of earthquake failure process. Although the observed seismicity patterns are very complex, the fundamental physical mechanism may be simple. The complex structures of the fault zone may be primarily responsible for the variation of the observed seismicity patterns. In this approach, rigorous definition of seismicity patterns and uniformity of the catalors are less important than in the first approach. Although seismicity patterns thus somewhat loosely defined may not be used directly for prediction purposes, they can be used to identify a possible physical mechanism. Once a physical mechanism is identified, other means such as monitoring temporal variations of source mechanism, spectra and wave forms may be used for prediction purposes. In view of the large degree of non-uniformity of the presently available seismicity catalogs and of the methods used by various investigators, we will be primarily concerned with the second approach in this paper.

\section{Examples of Seismicity Patterns}

Various seismicity patterns which have been reported so far are summarized in Table 1 in terms of the elementary patterns described in the Introduction. Although these results provide a fundamental data base for the present study, we made a global survey of seismicity patterns associated with large earthquakes by using spacetime plots of seismicity in order to clarify the nature and regional variation of seismicity patterns.

We used the NOAA catalog for all of the regions except for Japan. Since the uncertainty in the locaticn is probably about 30 to $50 \mathrm{~km}$, we will be primarily concerned with the patterns for earthquakes larger than magnitude 7.5 (The longperiod magnitude, $\mathrm{M}_{\mathrm{W}}$, is preferred whenever available. If it is not available, the surfacewave magnitude, $M_{S}$, is used.) whose rupture length is $70 \mathrm{~km}$ or larger.

The non-uniformity of the catalogues results from combinations of many factors which include: 1) temporal variations in the number and distribution of stations, 2) changes in the practice of the magnitude deterrination both at the individual stations and the central agency, 3) changes in the instruments, 4) changes in the personnel and the operation practice at the individual stations, and 5) changes in the location procedure. It is not clear how we can remove the effect of all of these factors to extract the real spatio-temporal variations of seismicity. Hence, we will plot the raw data from routinely available catalogues without heavy processing. Symbols with different sizes are used for different magnitude ranges to facilitate visual inspection of the patterns. As will be shown later, it is encouraging that some patterns are discernible from the space-time plots produced in this manner from routinely available catalogues. We first illustrate the method for Mexico.

\section{Mexico}

We extracted all the events shallower than $60 \mathrm{~km}$ which occurred within the box shown in the index map (Figure 2). Then the distance to the individual epicenter from the pole shown in Figure 2 was measured and the events were plotted as a function of time in the form of a space-time plot as shown in Figure 3. The pole is placed on the approximate extention of the strike of the region considered, and at a distance comparable to the total length 
TABLE 1. OBSERVED SEISMICITY PATTERNS ${ }^{*}$

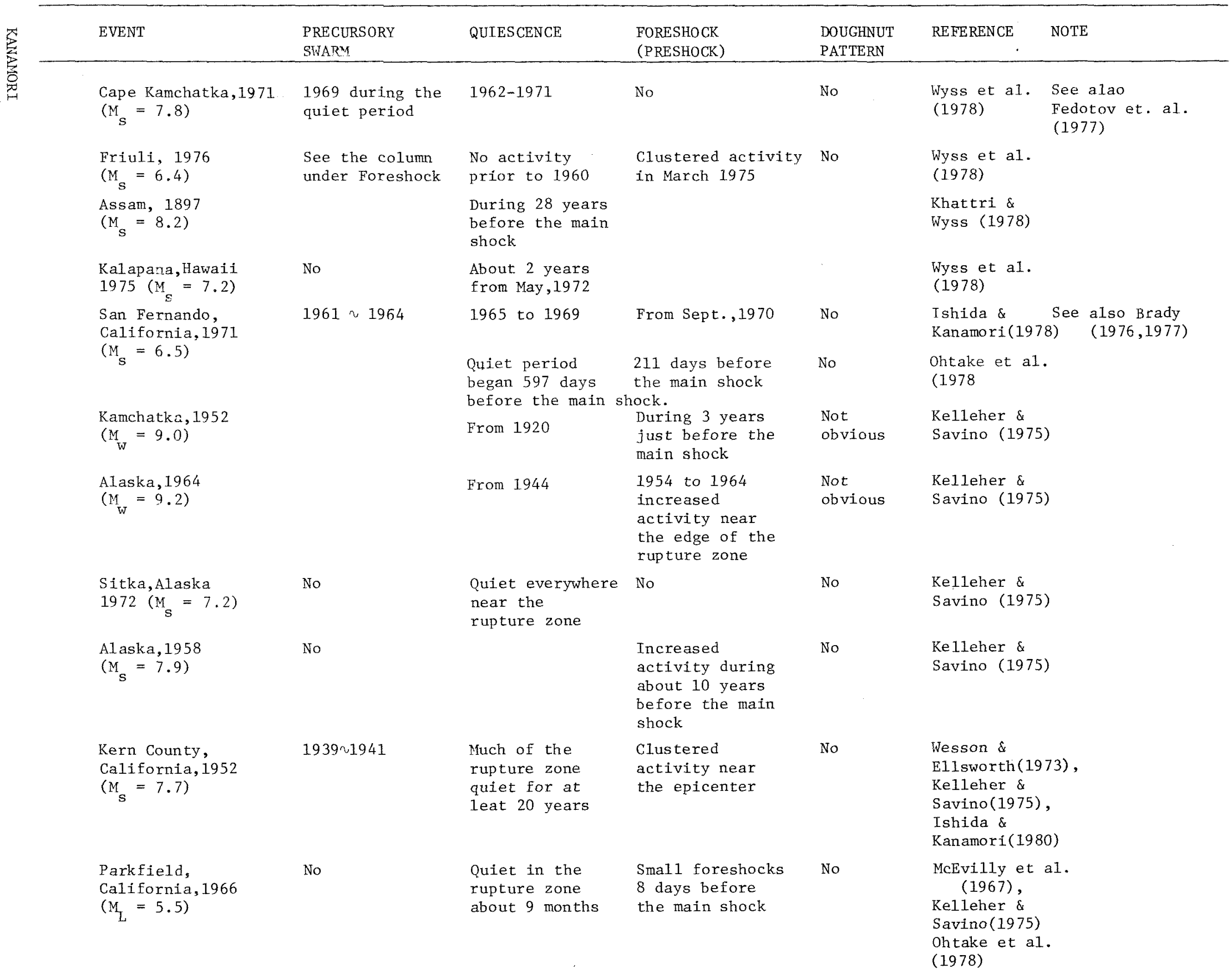


Table 1. cont'd.

\begin{tabular}{|c|c|c|c|c|c|}
\hline EVENT & $\begin{array}{l}\text { PRECURSORY } \\
\text { SWARM } \\
\end{array}$ & QUIESCENCE & $\begin{array}{l}\text { FORESHOCK } \\
\text { (PRESHOCK) }\end{array}$ & $\begin{array}{l}\text { DOUGHNUT } \\
\text { PATTERN }\end{array}$ & REFERENCE \\
\hline $\begin{array}{l}\text { Chile, } 1960 \\
\left(M_{W}=9.5\right)\end{array}$ & & $\begin{array}{l}\text { Quiet for at } \\
\text { least about } \\
5 \text { to } 8 \text { years }\end{array}$ & $\begin{array}{l}\text { Immediate } \\
\text { foreshocks } \\
\text { ( } 33 \text { hours before } \\
\text { the main shock) }\end{array}$ & No & $\begin{array}{l}\text { Kelleher \& } \\
\text { Savino }(1975)\end{array}$ \\
\hline \multirow[t]{2}{*}{$\begin{array}{l}\text { Tokachi-oki, } 1952 \\
\left(\mathrm{M}_{\mathrm{w}}=8.1\right)\end{array}$} & \multirow[t]{2}{*}{ No } & $\begin{array}{l}1943 \text { to } 1951 \\
1926 \text { to } 1951 \\
1934 \text { to } 1947\end{array}$ & $\begin{array}{l}\text { Increased activity } \\
\text { during } 1948 \text { to } 1952\end{array}$ & \multirow[t]{2}{*}{ Yes } & $\begin{array}{l}\text { Mogi }(1969) \\
\text { Utsu }(1968) \\
\text { Inouye }(1965)\end{array}$ \\
\hline & & 1937 to 1949 & $\begin{array}{l}2 \text { years before the } \\
\text { main shock }\end{array}$ & & $\begin{array}{l}\text { Katsumata (1978), } \\
\text { Katsumata \& Yoshida (1980) }\end{array}$ \\
\hline $\begin{array}{l}\text { Tonankai, } 1944 \\
\left(M_{W}=8.1\right) \text { and } \\
\text { Nankaido, } 1946 \\
\left(M_{W}=8.1\right)\end{array}$ & \multirow[t]{2}{*}{ No } & 20 years & No & Yes & Mogi (1969) \\
\hline $\begin{array}{l}\text { Sanriku, } 1933 \\
\left(\mathrm{M}_{\mathrm{W}}=8.4\right)\end{array}$ & & 1.2 years & No & Yes & Mogi (1969) \\
\hline $\begin{array}{l}\text { Tokachi-oki, } 1968 \\
\left(\mathrm{M}_{\mathrm{W}}=8.2\right)\end{array}$ & \multirow[t]{3}{*}{ No } & $\begin{array}{l}1961 \text { to main } \\
\text { shock except } \\
1965\end{array}$ & & \multirow[t]{3}{*}{ Yes } & Mogi (1969) \\
\hline & & 1948 to 1963 & \multirow[t]{2}{*}{$\begin{array}{l}\text { Increased activity } \\
\text { near the epicenter } \\
1964 \text { to } 1968\end{array}$} & & $\begin{array}{l}\text { Katsumata \& } \\
\text { Yoshida }(1980)\end{array}$ \\
\hline & & 1962 to May 1968 & & & Habermann (1980) \\
\hline $\begin{array}{l}\text { Shimane, Japan } \\
1978\left(\mathrm{M}_{\mathrm{JMA}}=6.1\right)\end{array}$ & No & $\begin{array}{l}5 \text { months before } \\
\text { the main shock }\end{array}$ & No & Yes & $\begin{array}{l}\text { Yamashina \& } \\
\text { Inove }(1979)\end{array}$ \\
\hline $\begin{array}{l}\text { Oaxaca, Mexico } \\
1978\left(\mathrm{M}_{\mathrm{w}}=7.6\right)\end{array}$ & No & $\begin{array}{l}\text { About } 5 \text { years } \\
\text { before the } \\
\text { main shock }\end{array}$ & Yes & No & $\begin{array}{l}\text { Ohtake et a1. } \\
(1977), \text { Ponce } \\
\text { et al. }(1977-78)\end{array}$ \\
\hline $\begin{array}{l}\text { Oaxaca, Mexico } \\
1968\left(\mathrm{M}_{\mathrm{s}}=7.1\right)\end{array}$ & No & 1966 to 1968 & \multicolumn{2}{|c|}{$\begin{array}{l}\text { Increased activity No } \\
\text { just before main shock }\end{array}$} & $\begin{array}{l}\text { Ohtake et a1. } \\
(1977)\end{array}$ \\
\hline $\begin{array}{l}\text { Oaxaca, Mexico } \\
1965\left(\mathrm{M}_{\mathrm{S}}=7.6\right)\end{array}$ & No & 1964 & $\begin{array}{l}\text { Preshocks } \\
1 \text { year before } \\
\text { main shock }\end{array}$ & No & $\begin{array}{l}\text { Oh take et al. } \\
(1977)\end{array}$ \\
\hline $\begin{array}{l}\text { Milford Sound, } \\
\text { New Zealand, } \\
1976\left(M_{L}=7.0\right)\end{array}$ & 1968 & 1969 to 1975 & & & Evison (1977a) \\
\hline $\begin{array}{l}\text { Borrego Mountain, } \\
\text { California, } 1968 \\
\left(\mathrm{M}_{L}=6.4\right)\end{array}$ & 1965 & $\begin{array}{l}1965 \text { to } 1967 \\
\text { About } 1 \text { year }\end{array}$ & $\begin{array}{l}\text { Yes } \\
\text { Increased activity } \\
\text { for } 395 \text { days }\end{array}$ & No & $\begin{array}{l}\text { Evison }(1977 a) \\
\text { Ohtake et al. } \\
(1978)\end{array}$ \\
\hline $\begin{array}{l}\text { Mendocino Ridge, } \\
\text { California, } 1960 \\
\left(M_{L}=6.2\right)\end{array}$ & 1959 & 1959 to 1960 & No & No & Evison (1977b) \\
\hline
\end{tabular}


Table 1. cont'd.

\begin{tabular}{|c|c|c|c|c|c|}
\hline EVENT & $\begin{array}{l}\text { PRECURSORY } \\
\text { SWARM } \\
\end{array}$ & QUIESCENCE & $\begin{array}{l}\text { FORESHOCK } \\
\text { (PRESHOCK) }\end{array}$ & $\begin{array}{l}\text { DOUGHNUT } \\
\text { PATTERN }\end{array}$ & REEERENCE \\
\hline $\begin{array}{l}\text { Gulf of California } \\
1966\left(M_{L}=6.3\right)\end{array}$ & 1963 & 1963 to 1966 & No & No & Evison (1977b) \\
\hline $\begin{array}{l}\text { Gisborne, } \\
\text { New Zealand, } 1966 \\
\left(M_{L}=6.2\right)\end{array}$ & August 1964 & $\begin{array}{l}\text { Sept } 1964 \text { to } \\
\text { Jan } 1966\end{array}$ & No & No & Evison $(1977 \mathrm{c})$ \\
\hline $\begin{array}{l}\text { Seddon, } \\
\text { New Zealand, } 1966 \\
\left(M_{L}=6.0\right)\end{array}$ & October 1964 & $\begin{array}{l}\text { Nov } 1964 \text { to } \\
\text { March } 1966\end{array}$ & No & No & Evison $(1977 \mathrm{c})$ \\
\hline $\begin{array}{l}\text { Inangahua, } \\
\text { New Zealand, } 1968 \\
\left(M_{L}=7.1\right)\end{array}$ & 1962 & 1963 to 1967 & No & No & Evison $(1977 \mathrm{c})$ \\
\hline $\begin{array}{l}\text { Hastings, } \\
\text { New Zealand, } 1973 \\
\left(M_{L}=5.7\right)\end{array}$ & March 1972 & $\begin{array}{l}\text { April } 1972 \text { to } \\
\text { Jan } 1973\end{array}$ & No & No & Evison $(1977 c)$ \\
\hline $\begin{array}{l}\text { Off Izu Peninsula } \\
\text { Japan, } 1974 \\
\left(\mathrm{M}_{\mathrm{JMA}}=6.9\right)\end{array}$ & $\begin{array}{l}1963 \text { to } 1965 \\
1961 \text { to } 1966\end{array}$ & $\begin{array}{l}1965 \text { to } 1974 \\
1967 \text { to } 1974\end{array}$ & & $\begin{array}{l}\text { No } \\
\text { No }\end{array}$ & $\begin{array}{l}\text { Sekiya }(1977) \\
\text { Ohtake }(1976)\end{array}$ \\
\hline $\begin{array}{l}\text { Central Gifu, } \\
\text { Japan, } 1969 \\
\left(M_{\text {JMA }}=6.6\right)\end{array}$ & & $\begin{array}{l}\text { About } 5 \text { years } \\
\text { before the } \\
\text { main shock }\end{array}$ & & & Sekiya (1977) \\
\hline $\begin{array}{l}\text { Choshi, Japan } \\
1974 \\
\left(\mathrm{M}_{\text {JMA }}=6.1\right)\end{array}$ & $\begin{array}{l}3 \text { years and } 5 \\
\text { months before } \\
\text { main shock }\end{array}$ & & Some foreshocks & No & Sekiya (1977) \\
\hline $\begin{array}{l}\text { Fukui, Japan } \\
1948 \\
\left(\mathrm{M}_{\mathrm{JMA}}=7.3\right)\end{array}$ & $\begin{array}{l}19 \text { years and } 3 \\
\text { months before } \\
\text { the main shock }\end{array}$ & & & & Sekiya (1977) \\
\hline $\begin{array}{l}\text { N. Miyagi, Japan } \\
1962\left(\mathrm{M}_{\text {JMA }}=6.5\right.\end{array}$ & 1956 to 1958 & & & & Sekiya (1977) \\
\hline $\begin{array}{l}\text { Shizuoka, Japan } \\
1965\left(\mathrm{M}_{\mathrm{JMA}}=6.1\right)\end{array}$ & $\begin{array}{l}4 \text { years before } \\
\text { the main shock }\end{array}$ & & & & Sekiya (1977) \\
\hline $\begin{array}{l}\text { Ebino, Japan } \\
1975\left(\mathrm{M}_{\text {JMA }}=4.1\right)\end{array}$ & $\begin{array}{l}\text { About } 15 \text { days } \\
\text { before the } \\
\text { main shock }\end{array}$ & & & & Sekiya (1977) \\
\hline $\begin{array}{l}\text { Kanto, Japan } \\
1923\left(M_{\mathrm{W}}=7.9\right)\end{array}$ & & & $\begin{array}{l}\text { About } 82 \text { years } \\
\text { before the } \\
\text { main shock }\end{array}$ & & Sekiya (1977) \\
\hline
\end{tabular}


Table 1. cont"d.

\begin{tabular}{|c|c|c|c|c|c|c|}
\hline EVENT & $\begin{array}{l}\text { PRECURSORY } \\
\text { SWARM }\end{array}$ & QUIES CENCE & $\begin{array}{l}\text { FORESHOCK } \\
\text { (PRESHOCK) }\end{array}$ & $\begin{array}{l}\text { DOUGHNUT } \\
\text { PATTERN }\end{array}$ & REFERENCE & NOTE \\
\hline $\begin{array}{l}\text { Central Aleutian, } \\
1976\left(\mathrm{~m}_{\mathrm{b}}=5\right)\end{array}$ & & $\begin{array}{l}4-1 / 2 \text { months } \\
\text { prior to the } \\
\text { main shock }\end{array}$ & $\begin{array}{l}6 \text { foreshocks } \\
\text { during } 5 \text { week } \\
\text { period }\end{array}$ & & \multicolumn{2}{|l|}{$\begin{array}{l}\text { Engdah1 \& } \\
\text { Kisslinger } \\
(1977)\end{array}$} \\
\hline $\begin{array}{l}\text { Markansu, } \\
\text { Centra1 Asia } \\
1974\left(M_{s}=7.4\right)\end{array}$ & $\begin{array}{l}\text { About } 7 \text { years } \\
\text { before main shock }\end{array}$ & 1968 to 1974 & & & \multicolumn{2}{|l|}{$\begin{array}{l}\text { Kristy \& } \\
\text { Simpson(1980) }\end{array}$} \\
\hline $\begin{array}{l}\text { Zaalai, } \\
\text { Central Asia } \\
1978\left(M_{\mathrm{s}}=6.7\right)\end{array}$ & $\begin{array}{l}\text { About } 2 \text { years } \\
\text { after main shock }\end{array}$ & & & & \multicolumn{2}{|l|}{$\begin{array}{l}\text { Kristy } \& \\
\text { Simpson }(1980)\end{array}$} \\
\hline $\begin{array}{l}\text { Imperial valley, } \\
\text { California } \\
1979\left(\mathrm{M}_{\mathrm{s}}=6.9\right)\end{array}$ & $\begin{array}{l}\text { About } 4 \text { months } \\
\text { before the } \\
\text { main shock }\end{array}$ & $\begin{array}{l}\text { About } 3-1 / 2 \\
\text { months before } \\
\text { the main shock }\end{array}$ & Yes & & \multicolumn{2}{|l|}{$\begin{array}{l}\text { Johnson \& } \\
\text { Hutton }(1980)\end{array}$} \\
\hline $\begin{array}{l}\text { Off Fukushima, } \\
\text { Japan, } 1938 \\
\left(\mathrm{M}_{\mathrm{JMA}}=7.7\right)\end{array}$ & & $\begin{array}{l}\text { Quiet at least } \\
\text { from } 1926 \text { to } \\
1933\end{array}$ & $\begin{array}{l}\text { Increased } \\
\text { activity from } \\
1934 \text { to } 1938\end{array}$ & & \multicolumn{2}{|l|}{$\begin{array}{l}\text { Inouye } \\
\text { (1965) }\end{array}$} \\
\hline $\begin{array}{l}\text { Niigata, Japan } \\
1964\left(M_{H}=7.6\right)\end{array}$ & & 1946 to 1961 & $\begin{array}{l}\text { S1ight increase } \\
\text { in activity from } \\
1962\end{array}$ & & \multicolumn{2}{|l|}{$\begin{array}{l}\text { Inouye } \\
\text { (1965) }\end{array}$} \\
\hline $\begin{array}{l}\text { Aso, Japan } \\
1975\left(\mathrm{M}_{\mathrm{JMA}}=5.9\right)\end{array}$ & $\begin{array}{l}3 \text { days before } \\
\text { the main shock }\end{array}$ & $\begin{array}{l}1-1 / 2 \text { days } \\
\text { before the } \\
\text { main shock }\end{array}$ & $\begin{array}{l}\text { During } 30 \text { hours } \\
\text { before the } \\
\text { main shock }\end{array}$ & & $\begin{array}{l}\text { Mi tsunami } \\
\& \text { Kubotera } \\
(1977)\end{array}$ & $\begin{array}{l}\text { 3-dimensional } \\
\text { feature }\end{array}$ \\
\hline $\begin{array}{l}\text { Assam, } 1950 \\
\left(M_{W}=8.6\right)\end{array}$ & . & $>30$ years & & & $\begin{array}{l}\text { Khattri } \delta \\
\text { Wyss }(1978)\end{array}$ & $\begin{array}{l}\text { Similar } \\
\text { results for } \\
4 \text { other events } \\
\text { jn same area }\end{array}$ \\
\hline $\begin{array}{l}\text { Kurile Is., } \\
1963\left(\mathrm{M}_{W}=8.5\right)\end{array}$ & 1961 & & & & \multicolumn{2}{|l|}{$\begin{array}{l}\text { Katsumata* } \\
\& \text { Yoshida }\end{array}$} \\
\hline & & $\begin{array}{l}2.2 \text { years before } \\
\text { the main shock }\end{array}$ & & & \multicolumn{2}{|l|}{ Tanaka et al. } \\
\hline $\begin{array}{l}\text { Kurile Is., } \\
1969\left(\mathrm{M}_{\mathrm{W}}=8.2\right)\end{array}$ & $\begin{array}{l}1967 \text { to } 1969 \\
\text { Precursory activity }\end{array}$ & & & & \multicolumn{2}{|l|}{$\begin{array}{l}\text { Katsumata and } \\
\text { Yoshida (1980) }\end{array}$} \\
\hline Nemuro-Oki & & 1961 to 1971 & $\begin{array}{l}1972 \text { to } \\
\text { main shock }\end{array}$ & & \multicolumn{2}{|l|}{$\begin{array}{l}\text { Ratsumata } \\
\text { Yoshida(1980) }\end{array}$} \\
\hline $\begin{array}{l}\text { Wakayama, } 1968 \\
\& 1977 \\
(M=4.8,4.7)\end{array}$ & & 2 to 3 years & $\begin{array}{l}\text { A precursory } \\
\text { event }\end{array}$ & & \multicolumn{2}{|l|}{$\begin{array}{l}\text { Mizotie et a1. } \\
(1978)\end{array}$} \\
\hline
\end{tabular}




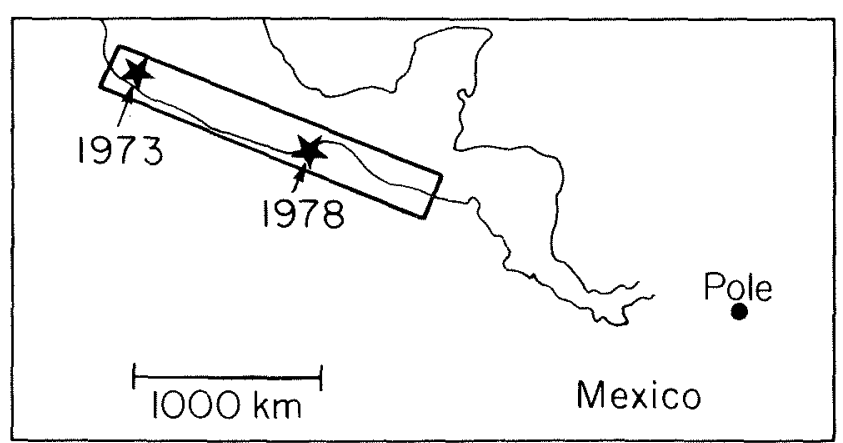

Fig. 2. Index map for Mexico. All the events shallower than $60 \mathrm{~km}$ which occurred in the box are shown in Fig. 3. The asterisks show the location of the 1973 Colima earthquake and the 1978 Oaxaca earthquake. The location of the pole is arbitrary, and the scale refers to the middle of the figure.

of the region. The pole position would not have a drastic effect on the overall pattern. The magnitude ranges for the larger symbols are indicated in the figure; the magnitude ranges for the events smaller than 6 are not indicated but the size of the symbols is approximately proportional to the magnitude. The dashed curves indicate the period of quiescence before the 1973 Colima and 1978 0axaca earthquakes. No rigid criterion is used for drawing these curves; they are drawn mainly to indicate the region being discussed rather than to define it. Therefore the estimate of the length of the quiet period and the size

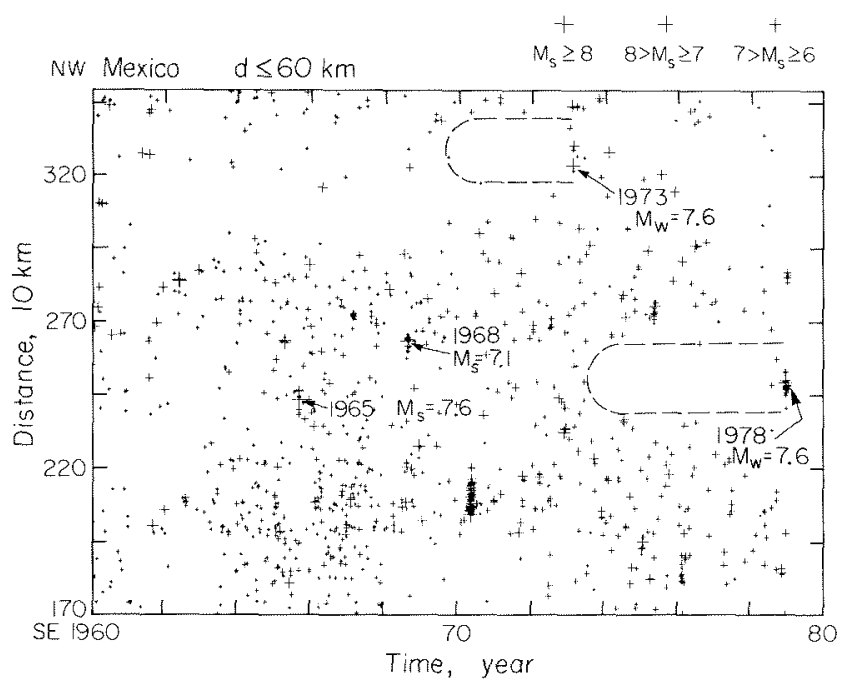

Fig. 3. Space-time plot of seismicity for Mexico obtained from the NOAA catalog (See Fig. 2 for the location). Dotted curves encircle the period of quiescence. The magnitude ranges for the larger symbols are indicated in the figures. The magnitude ranges for the events smaller than 6 are not indicated but the size of the symbols is approximately proportional to the magnitude. 


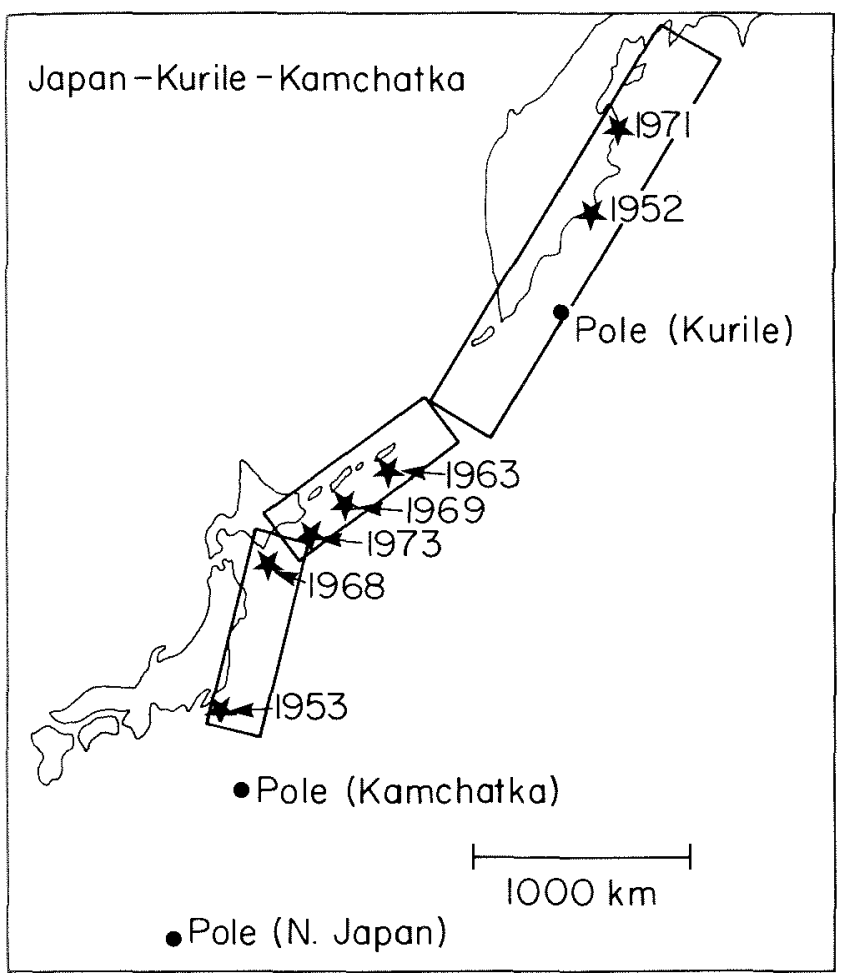

Fig. 4. Index map for the Kurile Is., Kamchatka and Northern Japan. For details, see caption for Fig. 2.

of the zone indicated by the dashed curves should not be given too much significance; no attempt is made here to use it for statistical arguments.

Since the detection capability, the location accuracy, the reporting procedure for the individual station, and the data reduction procedure are not uniform during this time period, the result shown here is inevitably nonuniform. For example, the sudden increase in the number of small events in 1963 is probably due to the establishment of the World Wide Seismographic Station Network (WWSSN). Also, the number of small events seems to have decreased abruptly in 1969. This sudden change could be an artifact of the reporting and the cataloguing procedures. Despite this nonuniformity, the quiescence before these two earthquakes, particularly the 1978 Jaxaca earthquake, appears very obvious. The quiescence before the Oaxaca earthquake was first noted by Ohtake et al. (1977) and was one of the basis of their forecast of this earthquake. The quiescence before the Colima earthquake is less pronounced, but the activity in the encircled area seems to be lower than that during the preceding time period. As seen in Figure 3, the Oaxaca earthquake was preceded by several foreshocks which were located by the world-wide network. At a smaller magnitude leve1, more than 10 foreshocks were located by a local network (Ponce et al., 1977-1978). For both the Oaxaca and
Colima earthquakes, no obvious precursory swarms or doughnut patterns are seen.

Ohtake et a1. (1977) reported a pattern of quiescence before the $1965\left(M_{S}=7.6\right)$ and 1968 $\left(M_{S}=7.1\right)$ Oaxaca earthquakes. Although there is some indication of reduced seismicity prior to these earthquakes, the pattern is not obvious on the scale of this plot (see Figure 3).

As seen in Figure 3, there are many quiet zones which are not followed by a large earthquake. It is important to note that while large earthquakes appear to be preceded by a period of quiescence, the mere existence of a quiet period does not necessarily point to an impending large earthquake.

We will proceed with a similar analysis for other seismic zones. The analysis method and the basic philosophy of interpretation will be the same unless noted otherwise.

Kurile

Figure 4 shows the index map for the Kurile, Kamchatka and Northern Japan regions. The result for the Kurile Islands is shown in Figure 5. During the period from 1960 to 1978, there were three events larger than 7.5, the 1963 event being the largest.

The 1963 event $\left(M_{W}=8.5\right)$ was preceded by a distinct period of quiescence. During 1961, the seismic activity became very high along a substantial length of the arc. This increase may be an artifact of increased number of reports from a regional network. However, it consists of many events with a magnitude larger than 6 , and is unlikely to be entirely due to nonuniformity of the catalog. For example, the numbers of events with $m_{\mathrm{H}} \geq 6.0$ which occurred within this box are 2, 3, 15 and 2 for 1959, 1960, 1961 and 1962 respectively. For events with $m_{b} \geq 6.3$, the corresponding numbers are 1, 2, 8 and 2. The 1963 earthquake was preceded by remarkable foreshock activity (e.g., Santô, 1964). Also, an increased activity during about a one year period before the mainshock is seen in Figure 5 .

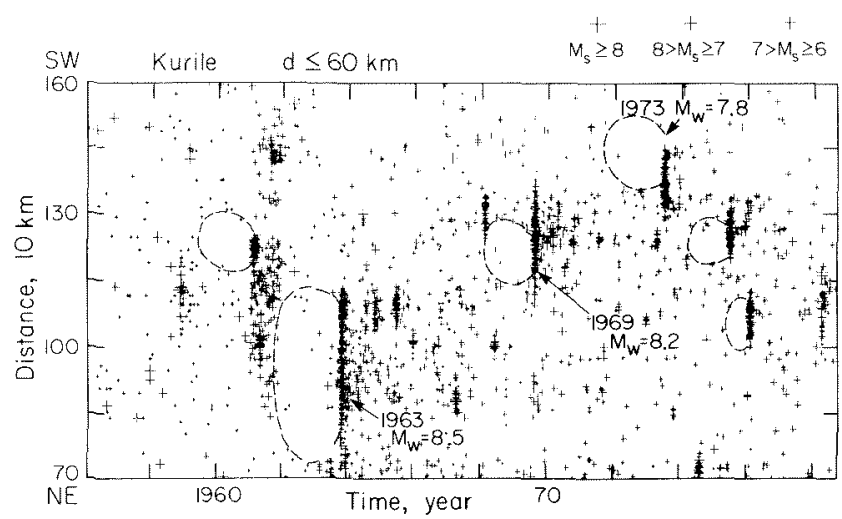

Fig. 5. Space-time plot of seismicity for the Kurile Is. region. See the caption for Fig. 3 for details. 
A similar pattern is seen for the 1969 Kurile Islands earthquake $\left(M_{\mathrm{w}}=8.2\right)$. This earthquake was preceded by several foreshocks during the 30 minute period before the mainshock. The pattern for the 1973 Nemuro-oki earthquake $\left(M_{\mathrm{W}}=7.8\right)$ is more or less similar to those for the 1963 and 1969 events, though the precursory swarm is not very distinct. The 1973 event was preceded by several small foreshocks.

Thus, for all three major earthquakes which occurred in the Kurile Islands since 1963, the swarm-quiescence-foreshocks pattern can be seen. Although the location accuracy is not good enough to investigate such patterns for smaller events, there is an indication that such patterns preceded smaller events in 1961, 1975 and 1976, as shown by dashed curves in Figure 5 .

\section{South America}

Figure 6 shows the index map for South America. Figure 7 shows the space-time plot for Chile. Although the data prior to 1960 are, in general, rather poor, it is very clear that $s \in i s m i c$ activity in the rupture zone of the 1960 Chilean earthquake $\left(M_{W}=9.5\right)$, the largest event in this century, had been lower than in the adjacent segment to the north during the preseismic period. This low activity has already been pointed out by Kelleher and Savino (1975). Because of the poor quality of the data, it is unclear when the quiet

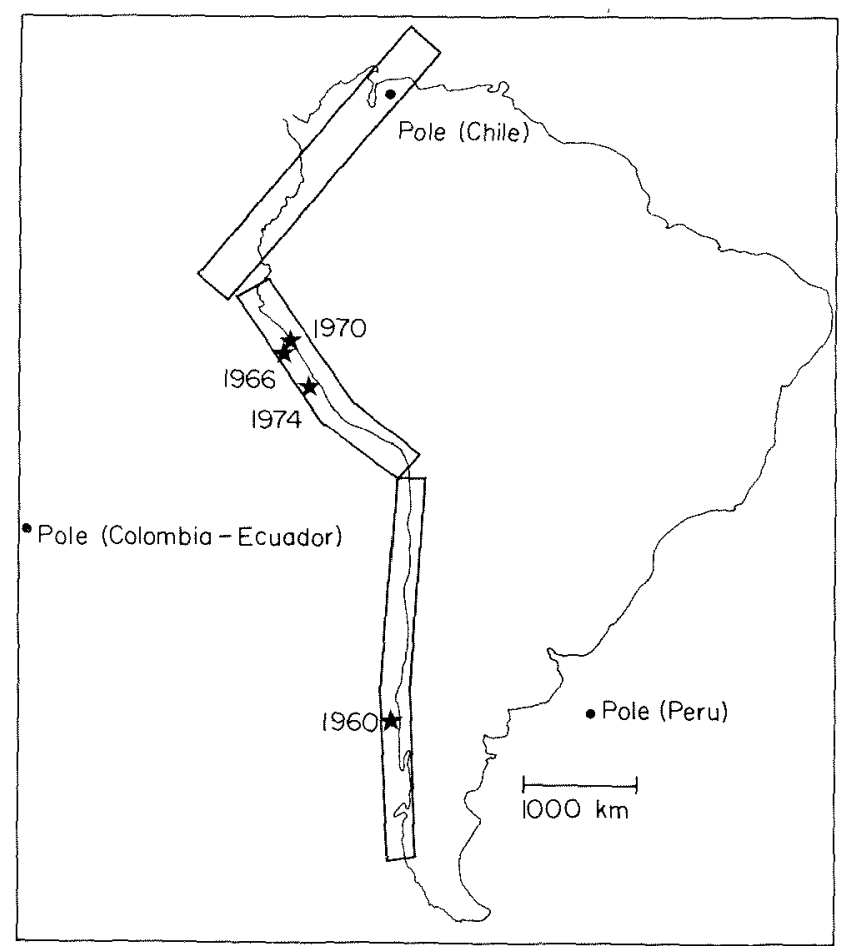

Fig. 6. Index map for South America. See caption for Fig. 2 for details.

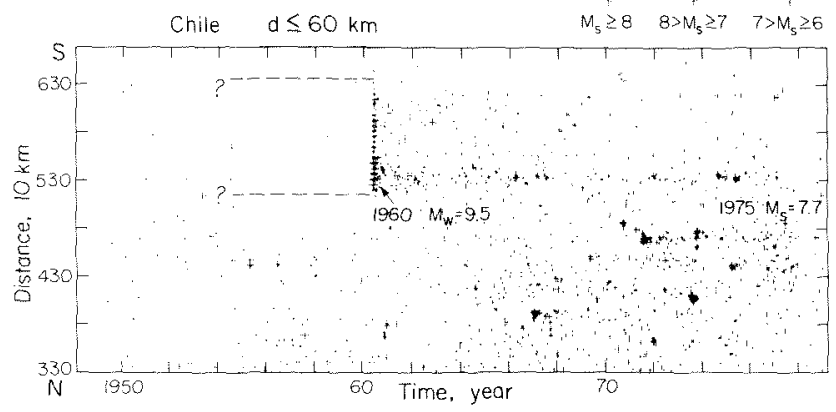

Fig. 7. Space-time plot of seismicity for Chile. See caption for Fig. 3 for details.

period started. The 1960 Chilean earthquake was preceded by remarkable foreshock activity during the 33 hour period just before the mainshock.

For the Peruvian subduction zone (see Figure 8), three events larger than 7.7 occurred during the period since 1960. The 1970 event $\left(M_{w}=7.9\right)$ occurred at a depth of about $70 \mathrm{~km}$ and probably represents failure within the down-going slab (Abe, 1972; Isacks and Barazangi, 1977). Since the location of this event is very close to that of the 1966 event, the pattern of seismicity for this event cannot be studied very well with the space-time plot used here. For both the 1966 $\left(M_{W}=8.1\right)$ and $1974\left(M_{W}=8.1\right)$ events, a period of seismic quiescence seems to have preceded the mainshock, as shown in Figure 8 . However, since the total number of events is relatively sma11, the statistical significance of these patterns is considered marginal. The pattern of precursory swarms and doughnut patterns are not evident. Neither of these events had foreshock activity detectable by the world-wide network.

For the Colombia-Ecuador subduction zone, the data are too sparse to study seismicity patterns.

\section{Alaska-Aleutians}

Figure 9 shows the locations of the seismic zones in the Alaska-Aleutians region studied here. Figure 10 shows the space-time plot for the 1964 Alaska earthquake $\left(M_{\mathrm{W}}=9.2\right)$ and the 1957 Fox Island earthquake $\left(M_{W}=9.1\right)$.

In constrast to the examples shown above, both of these earthquakes were preceded by a distinct increase in seismic activity which may be called a preshock activity during about 10 years before the mainshock. Although this increase may be due to increased detection capability, the fact that the commencement of the increased activity for the 1964 event differs from that of the 1957 event suggests that it represents a real seismicity change. This kind of increase in activity before large earthquakes concentrated near either end of the rupture zone, has already been pointed out by Kelleher and Savino (1975). This preshock activity was preceded by a relatively quiet period, although it is not very distinct compared with the 


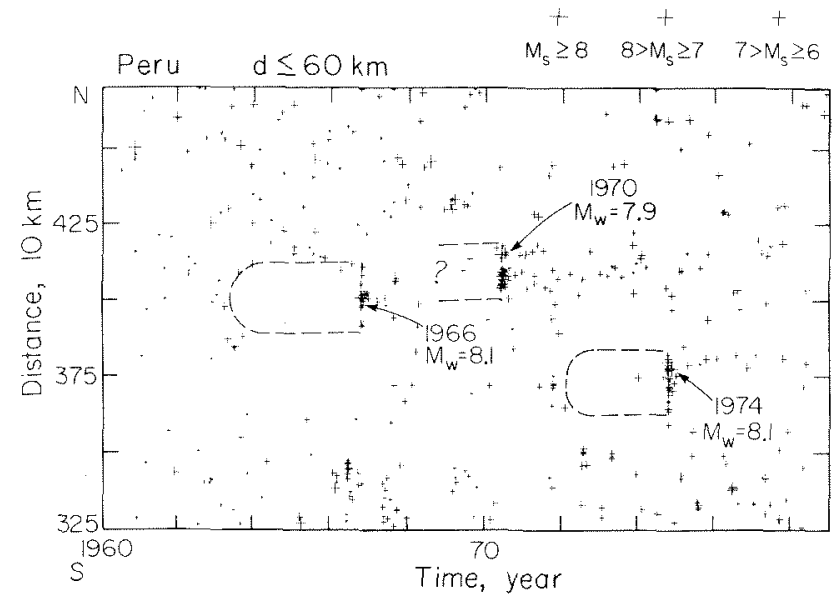

Fig. 8. Space-time plot of seismicity for Peru. See caption for Fig. 3 for details.

adjacent regions. During the period from 1928 to 1936, an increased level of seismic activity is seen in the rupture zone of both the 1964 and 1957 events. This activity may be considered to be a precursory swarm.

Figure 11 shows the pattern for the 1965 Rat Island earthquake $\left(\mathrm{M}_{\mathrm{w}}=8.7\right)$. The main feature of the seismicity pattern is similar to that of the 1964 and 1957 earthquakes. A relatively quiet period from 1957 to 1961 was followed by an increased level of activity for about 4 years, and there is some indication of an increased activity which may be considered to be a precursory swarm around 1956 .

Thus, all three major earthquakes in the AlaskaAleutian region have a common feature which is not observed in the other regions discussed above.

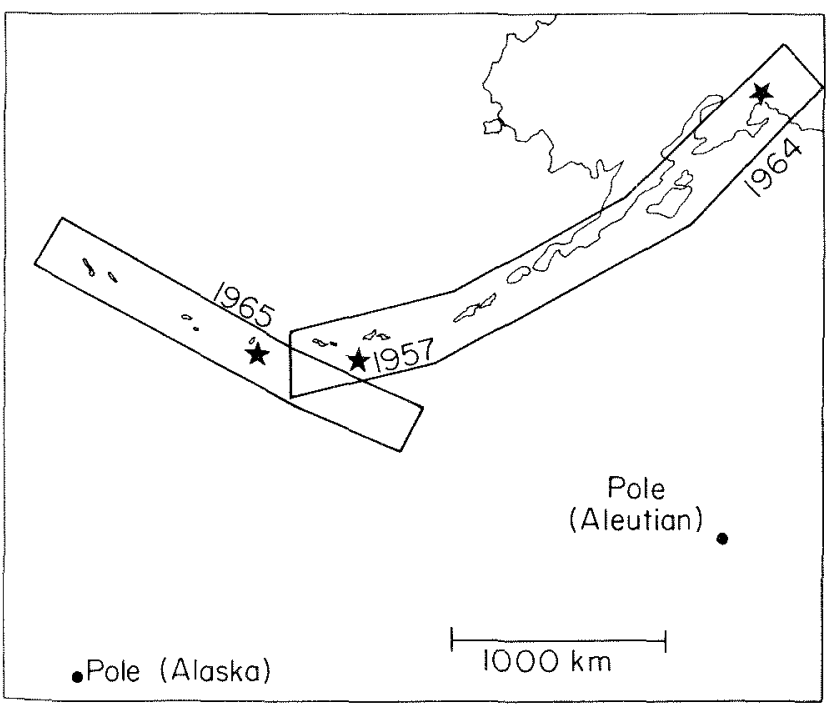

Fig. 9. Index map for Alaska and the Aleutians. See caption for Fig. 2 for details.

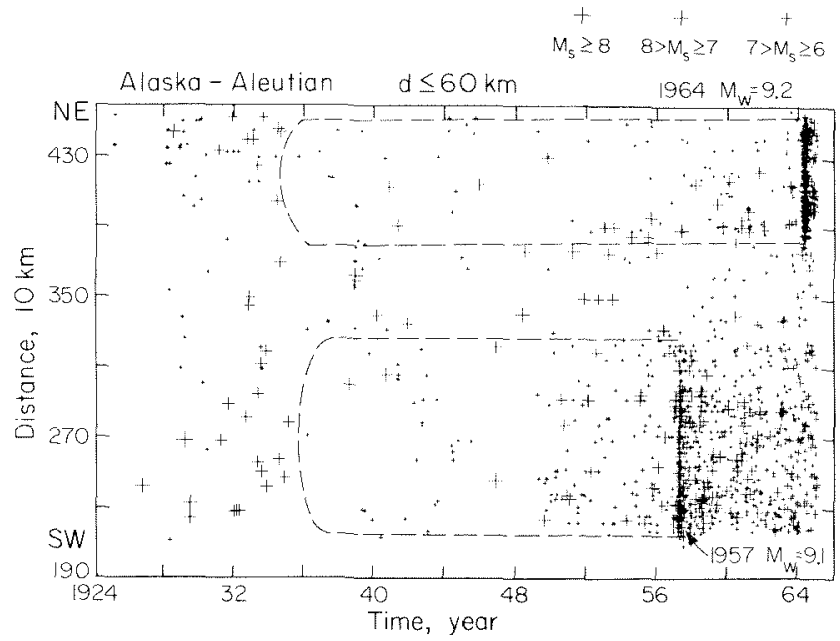

Fig. 10. Space-time plot of seismicity for the rupture zones of the 1964 Alaskan and the 1957 Fox Is. earthquake. For details, see caption for Fig. 3 .

\section{Kamchatka}

The area to be considered is shown in Figure 4, and the results are shown in Figures 12 and 13 . Figure 12 shows the result for the 1952 Kamchatka earthquake $\left(M_{W}=9.0\right)$. Unfortunately, the data are too incomplete to investigate the pattern. As Kelleher and Savino (1975) pointed out, a higher seismic activity than during the previous period is seen near the epicenter for about 3 years. Although the quiescence is not very clear, the seismic activity during the 15 year period from 1935 to 1950 appears lower than the preceding period.

Figure 13 shows the space-time plot for the period 1960 to 1978. During this period only one event larger than 7.6 occurred $\left(M_{S}=7.8,1971\right)$. However, the rupture zone for this event appears very small and no obvious pattern is seen on the scale shown here. Wyss et al. (1978) made a detailed analysis of this event and found a quiet period from 1962 to 1971 with a short period of increased activity in 1969. For a smaller event $\left(M_{S}=7.2\right)$ which occured in 1973, a period of

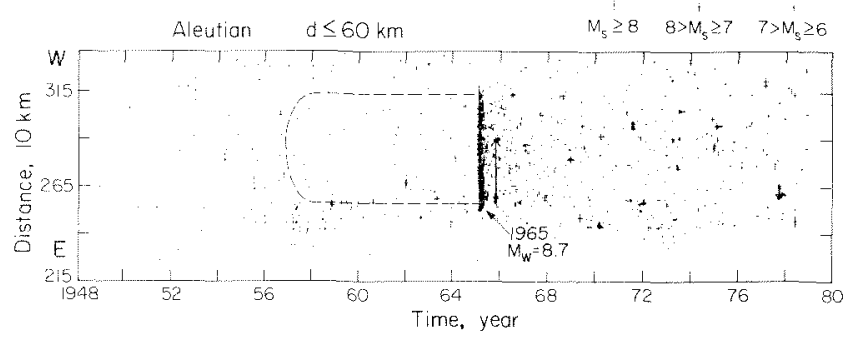

Fig. 11. Space-time plot of seismicity for the rupture zone of the 1965 Rat Is. earthquake. For details, see caption for Fig. 3 . 


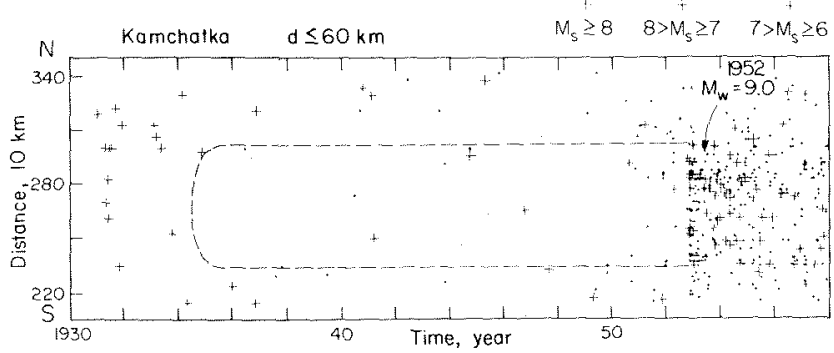

Fig. 12. Space-time plot of seismicity for the rupture zone of the 1952 Kamchatka earthquake. For details, see caption for Fig. 3.

quiescence may be identified (Figure 13). Wyss and Habermann (1979) examined seismicity within $100 \mathrm{~km}$ radius from the epicenter of this event, and concluded that a $50 \%$ decrease in seismicity rate began in mid 1967 . This period of quiescence can be identified also in the space-time plot shown in Eigure 13.

\section{Northern Japan}

Figure 14 shows the seismicity pattern for Northern Japan (see Figure 4 for the location). For this plot, the earthquake catalog compiled by the Japan Meteorological Agency (JMA) is used, and the earthquakes with $\mathrm{M}_{\text {JMA }}>5$ are shown. The largest earthquake during this time period is the 1968 Tokachi-oki earthquake $\left(\mathrm{M}_{\mathrm{W}}=8.2\right)$. The activity during about 3 years just before the mainshock is considerably lower than during the preceding period. No obvious foreshocks were reported for this earthquake, although Nagumo et al. (1968) recorded a number of very small events during several days before the mainshock by a oceanbottom seismograph which had been deployed in the epicentral area.

Mogi (1969), Katsumata and Yoshida (1980) and Habermann (1980) have made detailed analyses of seismicity patterns associated with this earthquake.

\section{Summary}

Both the results summarized in Table 1 and those described above show that many large earthquakes were preceded by a period of quiescence. Some events have a pronounced foreshock activity during a period of hours to weeks before the mainshock. Examples include earthquakes in the Kurile Islands (1963 and 1969), Nemuro-Oki (1973), and Chile (1960). Many large events in the Alaska-Aleutians and the Kamchatka regions tend to have an increased seismic activity during several years before the mainshock. However, some events do not have obvious forshocks or preshocks; examples are the large earthquakes in Peru and Northern Japan. Large earthquakes along the MidAmerica Trench were often preceded by moderate foreshocks (e.g., 1978 Oaxaca earthquake, 1979
Petatlan earthquake, Meyer et a1,, 1980). Thus there appears to be a fairly systematic regional. variation in the pattern for large earthquakes along various subduction zones. Precursory swarms and doughnut patterns are not always obvious in the space-time plot on regional scales, but detailed studies by other investigators have identified such patterns for some of the events.

\section{Asperity Model}

The coseismic motion on earthquake faults is often irregular as evidenced by complex wave forms of seismic waves generated by large earthquakes. This observation suggests that the fault plane is irregular either geometrically or in its physical or mechanical properties. The strength of the contact zone between the two sides of the fault is larger at some places than elsewhere. Such places of increased strength, either of geometrical origin or of some other causes, are generally called asperities. The importance of asperities in various failure processes was recognized in laboratory studies (Byerlee, 1970; Scholz and Engelder, 1976) and the concept of asperity has been frequently used in seismology, either explicitly or implicitly, to explain non-uniform seismicity along fault zones (Wesson and E11sworth, 1973; Bakun et a1., 1980) complex events (Wyss and Brune, 1967; Nagamune, 1971, 1978; Kanamori and Stewart, 1978; Lay and Kanamori, 1980a; Das and Aki, 1977; Aki, 1979), seismic clustering

(Ishida and Kanamori, 1978, 1980), and certain aspects of seismicity patterns (Mogi, 1977, Tsumura, 1979; Katsumata and Yoshida, 1980; Lay and Kanamori, 1980b).

Kanamori (1978) interpreted preseismic clustering of events near the main shock epicenter in terms of stress concentration around a strong asperity due to failure of weaker asperities surrounding it. Jones and Molnar (1979) explained observed time dependence of foreshocks by using a fault model with inhomogeneous contact planes on which asperities fail by static fatigue. Ebel

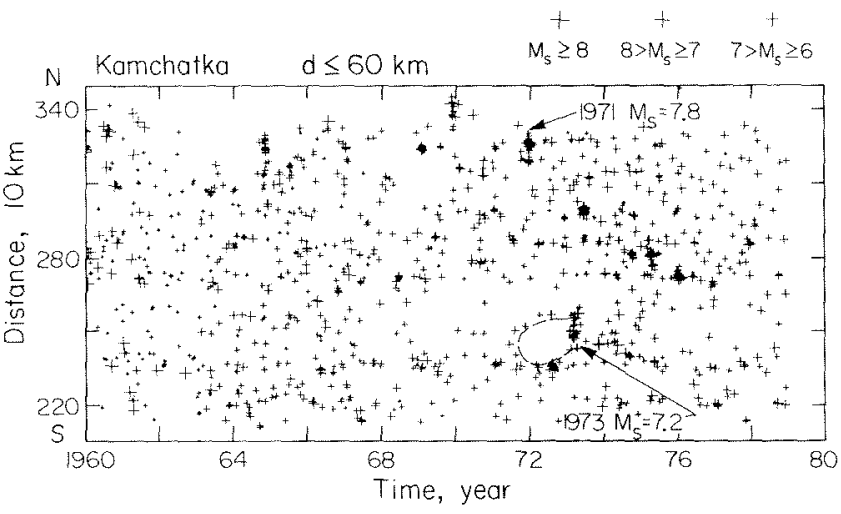

Fig. 13. Space-time plot of seismicity for the Kamchatka region for the period 1960 to 1978. For details, see caption for Fig. 3 . 


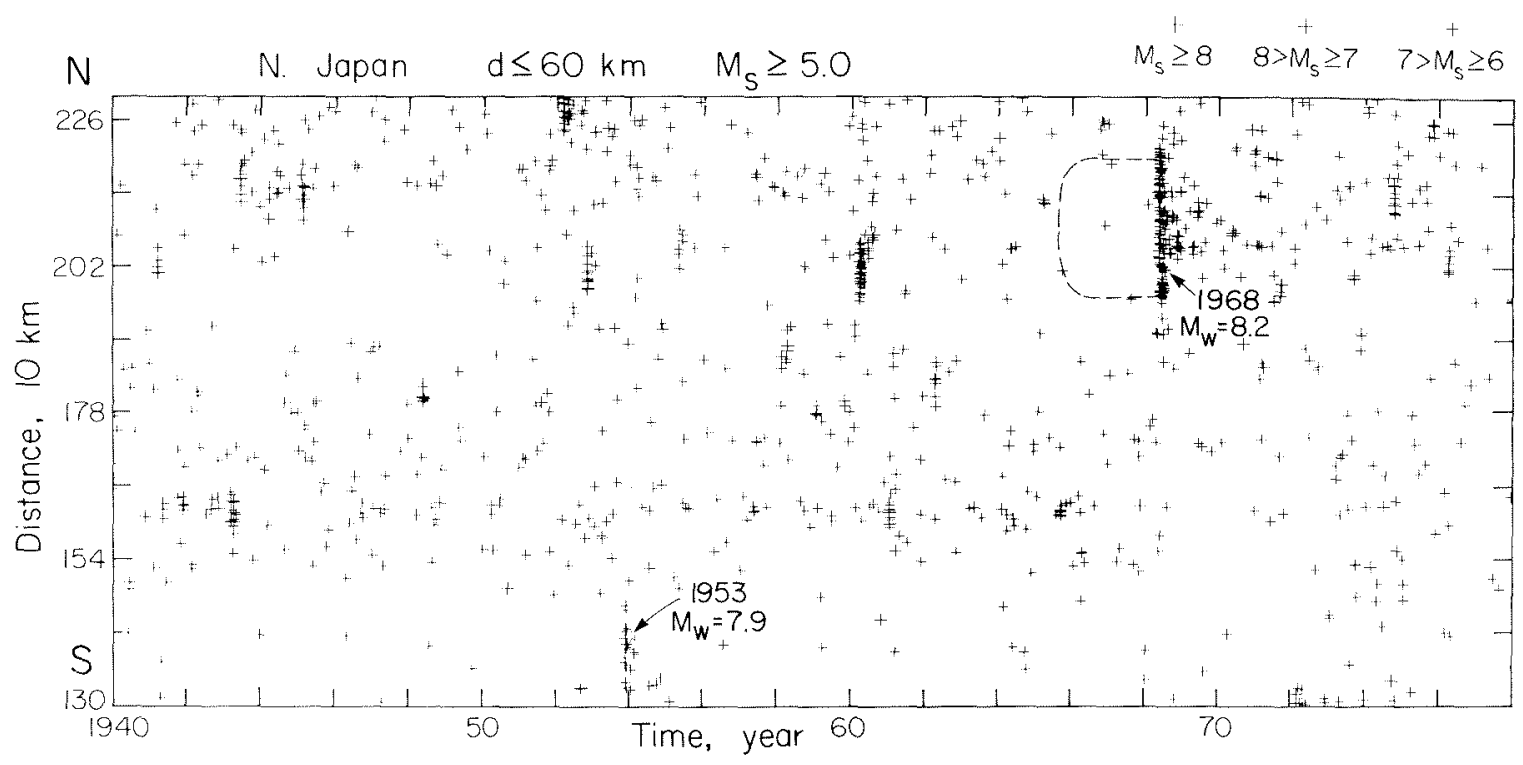

Fig. 14. Space-time plot of seismicity for Northern Japan obtained from the JMA catalog. Earthquakes smaller than 5 are not plotted.

(1980) interpreted a foreshock-main shock-aftershock sequence in the New Hebrides Islands in cerms of loading and subsequent failure of asperities on the fault plane.

Mogi (1977) explained the pattern of temporal seismic quiescence and doughnut patterns in terms of a heterogeneous stress distribution on the focal zone. As the tectonic stress increases, sma1l earthquakes occur at high-stress spots in the focal region of an impending large earthquake. When all the high stress spots are broken, the focal region becomes seismically quiet, but the activity in the surrounding region increases.

Tsumura (1979) argued that various seismicity patterns including foreshock patterns can be explained by introducing fault surfaces with variable strength. Katsumata and Yoshida (1980) proposed a model in which the coupling conditions between the 1ithospheric plates control the temporal variation of seismicity patterns.

Brune (1979) discussed the importance of heterogeneous stress distribution (asperity) on the fault plane as a controlling factor of various premonitory phenomena.

In order to explain the nature of various seismicity patterns presented in the previous section, we propose a very simple asperity model. As mentioned above, this type of asperity model has been used by various investigators in the past; the main emphasis here is to parameterize the model and relate it to the variation of observed seismicity patterns.

Figure 15 illustrates the model. The rectangular box represents all or part of the rupture surface. of a large earthquake, and hereafter is called a unit fault. The unit fault is divided into smaller subfaults. Let $s$ be the strength of the subfaults. In general, the strength of the fault surface is not uniform. Here we use, for simplic- ity, a Gaussian distribution with the average $\delta$ and the standard deviation $\Sigma$ to represent the variation of the strength (see Figure 15b). The details of the form of this distribution are unimportant for the present purpose.

An asperity is introduced as a region within this unit fault where the strength is higher than in the surrounding region (Figure 15a). Let $s_{a}$ be the strength of the subfaults located in the asperity. We assume that $s_{a}$ follows another Gaussian distribution with the average $B$ $\left(s_{>}>s\right)$ and the standard deviation $\Sigma a$. Thus the overall distribution of the strength of the subfaults on the fault surface is given by a bimodal distribution as shown by Figure 15b. Although the actual fault is more complex and may be more adequately represented by a multi-modal distribution, the bimodal distribution shown by Figure $15 \mathrm{~b}$ is introduced to isolate the effect of an asperity, and represents the simplest case.

We consider a loading stress $\sigma_{0}$, which varies linear $1 \mathrm{y}$ in time:

$$
\sigma_{0}=\sigma_{00}+\alpha t
$$

where $t$ is the time and $\sigma_{o o}$ and $\alpha$ are constants. When the stress at a grid point $(i, j)$ exceeds the strength of the subfault there, the subfault fails and the stress there drops to 0 . For simplicity, we assume that once a subfault fails, the fault surface there is decoupled (i.e., no healing takes place), and the loading stress $\sigma_{0}$ is held uniformly by the remaining subfaults. Thus, under this assumption, the stress at the subfault at $(i, j)$ is given by:

$$
\sigma(i, j)=\sigma_{0} /[1-(\ell / N)]
$$

where $\mathrm{N}$ is the total number of subfaults in the 


$$
\begin{aligned}
& s(i, j) \text { : Strength } \\
& s_{a}(i, j) \text { : Strength (Asperity) } \\
& \text { Loading Stress } \\
& \quad \sigma_{0}=\sigma_{00}+\alpha t \\
& \text { Stress at }(i, j) \\
& \quad \sigma(i, j)=\sigma_{0} \frac{1}{\left(1-\frac{l}{N}\right)} \\
& l: \text { Number of Broken Subfaults } \\
& N \text { : Total Number of Subfaults }
\end{aligned}
$$
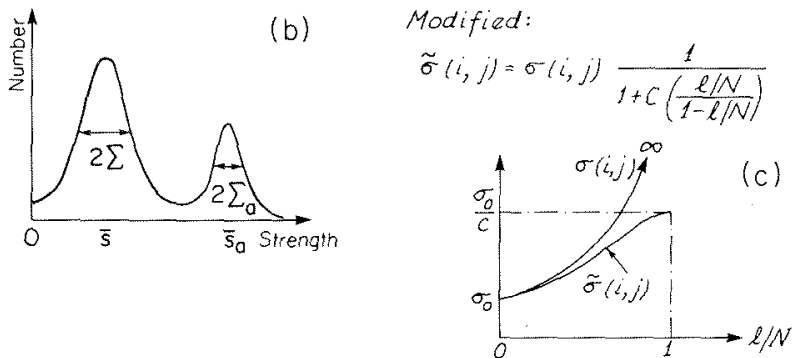

Fig. 15. Schematic figure showing a unit fault containing an asperity (a), the distribution of strength of subfaults within the asperity and the surrounding area (b), and the stress or on subfaults (c).

unit fault and $\ell$ is the number of broken subfaults. Thus, although the loading stress is linear in time, the rate of stress increase on unbroken faults is accelerated as the number of broken subfaults increases. This kind of accelerated instability due to failure of asperities has been used by Jones and Molnar (1979) to explain temporal variations of foreshocks. As \& approaches $N$, o tends to infinity. However, this is physically inplausible. Since the unit fault considered here (the rectangular box in Figure 15a) is not an isolated system, the loading stress will be partially held by the fault zones adjacent to the unit fault, as a large part of the unit fault is broken. Therefore the stress on the subfault will approach a finite value instead of becoming infinity. In order to accommodate this situation we introduce a constant $C$ and represent the stress on the subfault at $(i, j)$ by:

$$
\tilde{\sigma}(i, j)=\sigma(i, j) /\left[1+C\left(\frac{\ell / N}{1-\ell / N}\right)\right]
$$

which is shown in Figure $15 \mathrm{c}$ together with $\sigma(i, j)$. This modification is made in order to accommodate a physically more reasonable situation, but it does not affect our conclusion qualitatively.

According to this asperity model, the fallure sequence on the unit fault would be schematically shown by Figure 16. When the tectonic loading stress is relatively low $\tilde{\sigma}(i, j)$ is substantially lower than $\bar{s}$ so that a relatively small number of subfaults break as a scattered background activity, as shown by stage 1 in Figure 16 . As $\tilde{\sigma}$ approaches $\bar{S}$, a large number of subfaults fail and the process is accelerated resulting in a swarm-like activity, and $\tilde{\sigma}$ exceeds $\vec{\Delta}$ in a relatively short time. This stage (stage 2, Figure 16) corresponds to a precursory swarm. When this stage is passed, most subfaults outside the asperity are broken so that few subfaults fail as the tectonic stress increases, resulting in seismic quiescence (stage 3, Figure 16). At this stage, stress is concentrated on the asperity and the area surrounding the asperity is essentially decoupled. This situation may result in loading of the fault zones adjacent to the unit fault, and a doughnut pattern may develop. Finally, when $\tilde{\sigma}$ approaches $Z_{a}$, the asperity begins to break in an accelerated sequence in the form of a foreshocks-main shock sequence (stage 4, Figure 16). When the entire asperity breaks, sympathetic slip occurs in the area surrounding it, causing coseismic overall fault movement. If the effect of the sudden stress drop is large enough to trigger the adjacent fault zones, the event will develop into a more complex multiple event. After this entire sequence is completed, a new episode of stress loading begins, producing another earthquake cycle.

In order to see the above sequence in more detail, we made a simple numerical simulation. As shown by Figure 17b, a square unit fault is divided into 100 subfaults and nine of them near the center are designated as an asperity. A Gaussian random number table is used to assign variable strengths to the subfaults. By choosing the parameters as shown in Figure $17 \mathrm{~b}$ and $17 \mathrm{c}$, an earthquake sequence shown by Figure $17 \mathrm{c}$ can be generated. This sequence may be compared to one of the representative seismicity patterns, such as the one for the 1963 Kurile Islands earthquake shown in Figure 17a. The pattern shown in Figure $17 \mathrm{c}$ has a precursory swarm, seismic quiescence and foreshocks. The difference in time scale between Figure $17 \mathrm{a}$ and Figure $17 \mathrm{c}$ could be adjusted very easily by changing the model parameters and is not important. Among the most important parameters in this model are $\Sigma_{a}, \bar{s}_{a} / \bar{s}$ and $\Sigma$ which control the foreshock activity, quiescence and precursory swarm respectively. When $\Sigma_{a}$ is reduced, the asperity tends to fail in a single event without foreshocks as shown by Figure $17 \mathrm{~d}$. When the difference in the strength of the
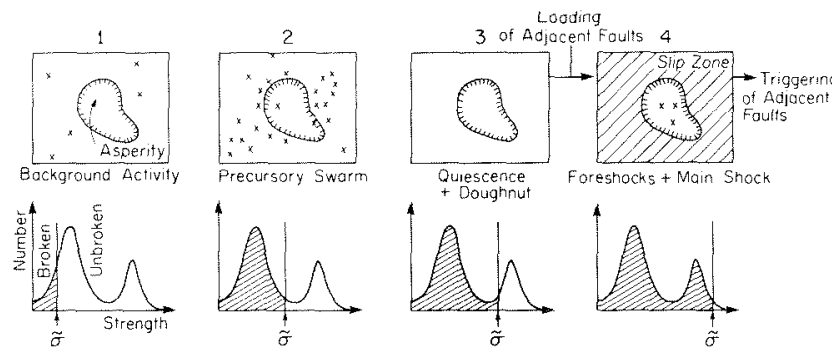

Fig. 16. Sequence of seismicity pattern predicted by the asperity model shown in Fig. $15 . \tilde{\sigma}$ is the stress on subfaults. 

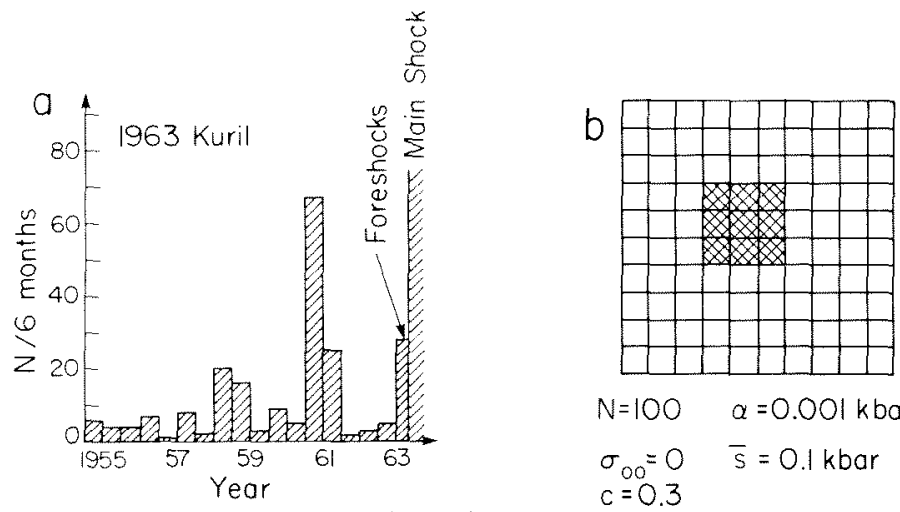

$$
\begin{array}{ll}
N=100 & \alpha=0.001 \mathrm{kbar} / \mathrm{yr} . \\
\sigma_{00}=0 & \overline{\mathrm{s}}=0.1 \mathrm{kbar} \\
c=0.3 &
\end{array}
$$
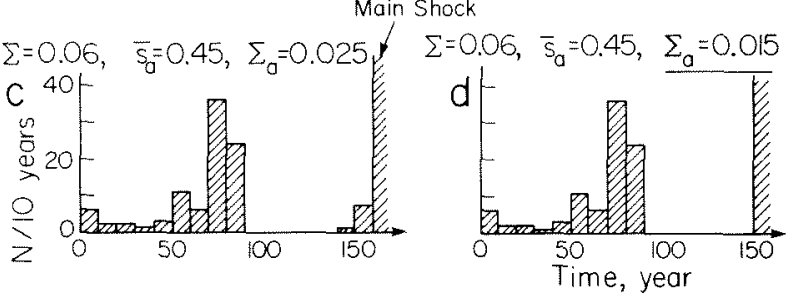

$\sum=0.1, \quad \bar{s}_{\mathrm{a}}=0.45, \quad \Sigma_{\mathrm{a}}=0.025$
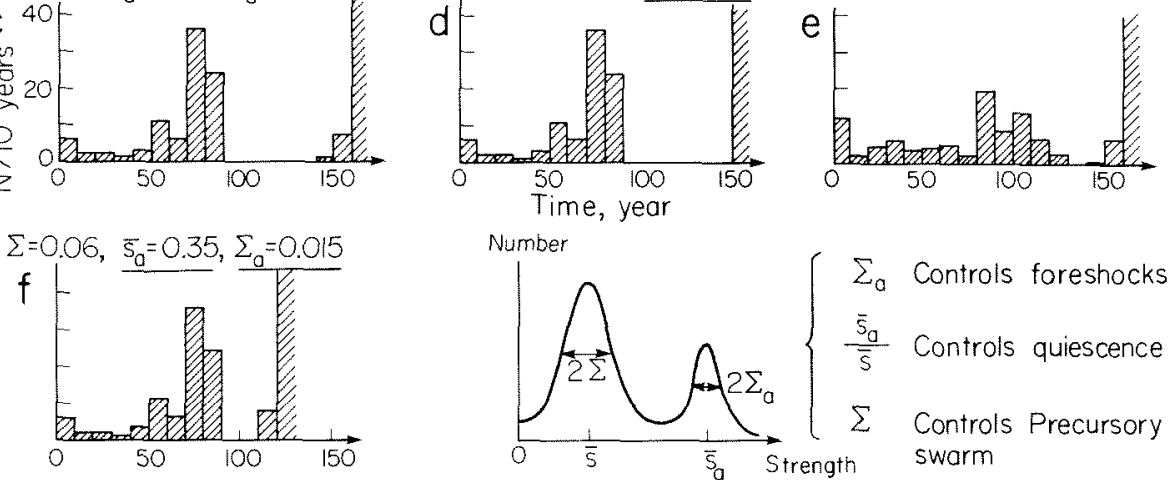

Fig. 17. Comparison of temporal variation of number of events between the 1963 Kurile Is. sequence and the asperity models.

asperity and the surrounding area is small (i.e., small $\left.\bar{s}_{a} / \bar{s}\right)$, the duration of the quiet period decreases (Figure 17f). This situation is similar to that discussed by Tsumura (1979). A large $\Sigma$ results in a spread-out precursory swarm activity as shown in Figure 17e.

In the model presented here, we did not consider any physical failure criterion, healing mechanism, anelastic time dependent mechanism or dynamic response of the medium. The primary purpose of this model is to provide the simplest possible model with which the variation and complexity of observed seismicity patterns can be reproduced. At present, our knowledge of the nature, distribution and regional variation of asperities on the fault is too limited to fully test this mode1. However, if this model proves useful for interpreting seismicity patterns, more physical and dynamic models such as the one developed by Mikumo and Miyatake (1979) need to be introduced to study further details of selsmicity patterns.

\section{Discussion}

Although it is not possible at present to test this model directly, it is desirable to investigate whether this model is reasonable in the light of available seismological data other than seismicity patterns.
Among the important consequences of this model in terms of observable seismological parameters are the clustering of events and increasing (in time) stress drops as schematically shown in Figure 18. The overall loading stress increases linearly with time. When a weaker subfault breaks, a stepwise increase in ơ occurs on other subfaults. Thus the stress drop of small earthquakes would increase as a function of time. Since the in situ condition is far more complex than is modeled here, one would expect a considerable variation in stress drops at a given time. Nevertheless, if the asperity model is correct, the stress drop should increase, on the average, as the final failure of the asperity approaches.

Since foreshocks and preshocks occur as a result of local stress concentration within the asperity, they would be tightly clustered in space and probably have the same mechanism. As a result, they would have approximately the same wave form, if the magnitude of the events is about the same. The mechanism of the preshocks may be different from the background mechanism.

Hamaguchi and Hasegawa (1975) studied a large number of aftershocks of the 1968 Tokachi-oki earthquake having similar wave forms, and concluded that these similar events occurred at approximately the same location under the same mechanical condition. Geller and Mueller (1980) 


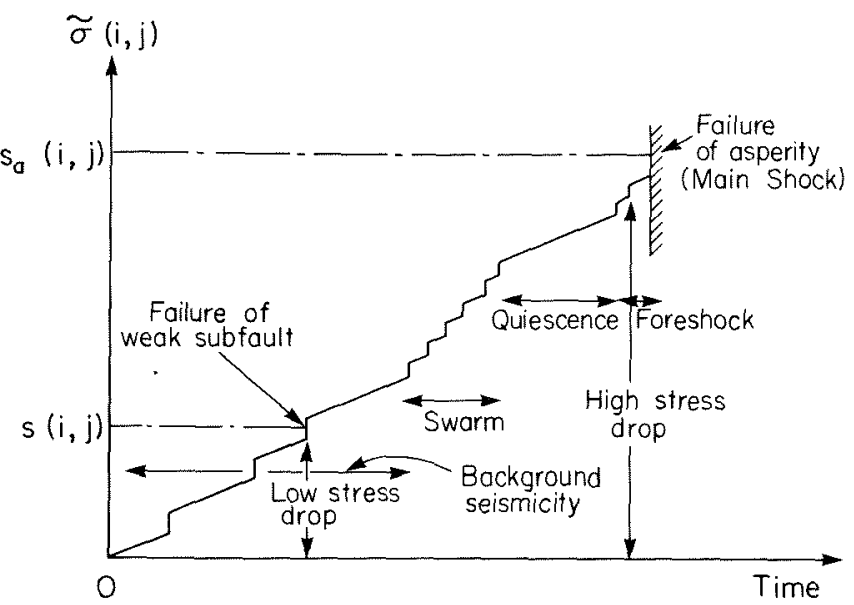

Fig. 18. Temporal variation of stress $\tilde{\sigma}$ at a subfault. A step-wise increase is caused by failure of another weaker subfault.

found four small earthquakes with similar wave forms on the San Andreas Fault in Central California, and suggested that they may represent breakings of an asperity where stress is repeatedly concentrated and released.

\section{Wave form}

There are not many high-quality data sets of wave forms for foreshocks or preshocks. Ishida and Kanamori (1978) found that the wave forms of all of the five events which occurred in the proximity of the epicenter of the 1971 San Fernando earthquake during about 2 years before the main shock were nearly identical to each other. Ishida and Kanamori interpreted this clustering and similarity of the wave forms in terms of stress concentration around an asperity whose failure led to the San Fernando earthquake.

For the 1974 Haicheng earthquake, Jones et al. (1980) found that most foreshocks can be classified into two groups, each having approximately the same wave form. For the 1979 Imperial Valley, California earthquake, the main shock was preceded by three foreshocks whose wave forms are very similar to each other, as shown in Figure 19 (James Pechmann, Personal communication, 1980).

These examples strongly indicate that a very tight clustering of activity which occurred more or less under the same stress preceded the main shock in the close proximity of the main shock rupture zone.

However, Tsujiura (1979) found that, while the wave forms of small events which preceded several earthquake swarms were very similar, those which occurred before several distinct main shock aftershock sequences varied considerably. Although the distinction between swarms and main shock aftershock sequences is not very obvious and whether the wave form is similar or not depends on the frequency band used, Tsujiura's observations suggest that the stress distribution near the epicenter of an impending earthquake can be very heterogeneous.

\section{Spectrum and Stress Drops}

Whether foreshocks and preshocks are higher stress drop events than the earlier events is as yet unresolved. Although several examples indicate that foreshocks had higher frequency content than other events, the quality of the data was somewhat limited.

Ishida and Kanamori (1980) analyzed the wave forms of small events which occurred near the epicentral area of the 1971 San Fernando and the 1952 Kern County earthquakes and found that foreshocks had, on the average, more highfrequency energy than the earlier events. Although these results are obtained with onestation data, they are based on very uniform broad-band data (Wood-Anderson seismograms) collected over a very long period of time, 10 and 18 years for the San Fernando and the Kern County earthquakes respectively. Since the characteristic time scale of earthquake loading cycles is at least 10 to 100 years, it is extremely important to have a long-term data base for this kind of study.

Some studies indicated, however, that the identification of foreshocks is not very straightforward. Tsujiura (1977) observed that some foreshocks had higher stress drops, but it was not always the case. Bakun and McEvilly (1979) examined several foreshocks and aftershocks of the 1966 Parkfield, California earthquake and concluded that the difference between the foreshocks and the aftershocks in terms of their frequency content is extremely subtle.

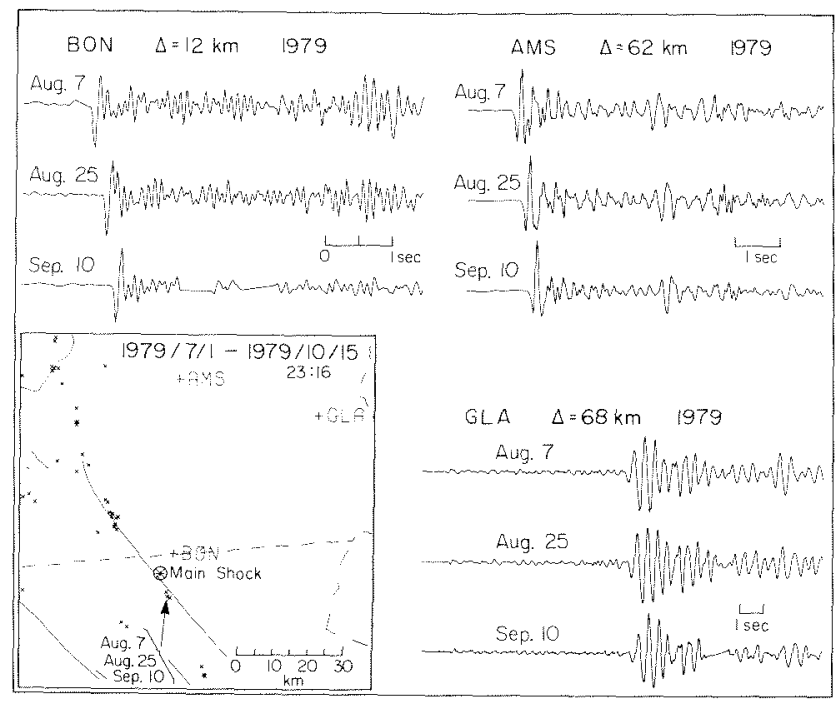

Fig. 19. Wave forms of three foreshocks of the 1979 Imperial Valley earthquake recorded at three stations. 
According to the numerical experiment described above, a ratio of 4 of the stress drop of foreshocks to other events would be enough to yield the observed seismicity patterns. In view of the large error in the measurements of stress drops, particularly for small events, detection of possible temporal variation of stress drops of this magnitude would be very difficult. Nevertheless, with a better (wider dynamic range, broader frequency band with digital recording) instrumentation, it will eventually be possible to make more accurate stress drop measurements for monitoring stress variation on a fault plane. In this regard, Archambeau's (1978) approach $\left(\mathrm{M}_{\mathrm{S}} / \mathrm{m}_{\mathfrak{b}}\right.$ ratio), House and Boatwright's (1978) analysis (use of local strong-motion record), and Mori's (1980) study (use of short-period WWSSN data) would have a very important potential for monitoring seismic gaps.

\section{Conclusion}

Although various seismicity patterns have been reported for many earthquakes, the nature of the patterns varies substantially from event to event. A global survey of seismicity patterns before major subduction-zone events indicates significant regional variations of the nature of seismicity patterns. It appears that the heterogeneity and the complexity of the individual fault zones are responsible for the observed variations. The fundamental physical process leading to an earthquake may be common to most events, but its manifestation as seismicity patterns may vary significantly depending upon the regional and local variations of the fault-zone structure. A very simple asperity model is presented in this paper to reproduce this situation. The basic physical process in this model is gradual stress concentration at an asperity on the fault zone. This stress concentration followed by failure of the asperity manifests itself as a variety of seismicity patterns depending upon the strength and heterogeneity of both the asperity and the surrounding area. Although it is not presently possible to test this model directly, it serves as a useful working model for a better understanding of earthquake precursors.

Although seismicity patterns provide important information on the earthquake preparatory process, its usefulness for prediction purposes is somewhat limited because of the substantial variations from event to event. However, the asperity model would suggest use of other seismological data such as wave forms, spectra and mechanism of preshocks for monitoring the state of stress on the fault plane, the key information for earthquake prediction.

\section{Acknowledgments. I thank Carl Johnson and} Bernard Minster for teaching me how to plot earthquakes by computer. I also thank Larry Ruff, Thorne Lay, Don Anderson and James Pechmann for many helpful comments on the manuscript. I benefited from comments by anonymous reviewers concerning several problems arising from nonuniformity of the catalog.

This work was partially supported by U.S. Geological Survey Contract No. 14-08-0001-18371. Contribution No. 3508, Seismological Laboratory, California Institute of Technology, Pasadena, California 91125 .

\section{References}

Abe, K., Mechanisms and tectonic implications of the 1966 and 1970 Peru earthquakes, Phys. Earth Planet. Interiors, 5, 367-379, 1972 .

Aki, K., Characterization of barriers on an earth quake fault, J. Geophys. Res., 84, 6140-6148, 1979.

Archambeau, C., Estimation of non-hydrostatic stress in the earth, by seismic methods: Lithospheric stress levels along Pacific and Nazca plate subduction zones, Proc. of Conference VI; Methodology for identifying seismic gap and soon-to-break gaps, U.S. Geological Survey Open-File Report 78-943, p. 47-138, 1978 .

Bakun, W. H., and T. V. McEvilly, Are foreshocks distinctive? Evidence from the 1966 Parkfield and the 1975 Oroville, California sequence, Bull. Seismol. Soc. Am., 69, 1027-1038, 1979.

Bakun, W. H., R. M. Stewart, C. G. Bufe, and S. M. Marks, Implication of seismicity for failure of a section of the San Andreas fault, Bu11. Seismo1. Soc. Am., 70, 185-201, 1980.

Brady, B. T., Theory of earthquakes, Pageoph., 114, 1031-1082, 1976.

Brady, B. T., Anomalous seismicity prior to rock bursts: Implications for earthquake prediction, Pageoph., 115, 357-374, 1977.

Brune, J. N., Implications of earthquake triggering and rupture propagation for earthquake prediction based on premonitory phenomena, J. Geophys. Res., 84, 2195-2198, 1979.

Byerlee, J. D., Static and kinetic friction of granite under high stress, Int. J. Rock Mech. Min. Sci., 7, 577-582, 1970 .

Das, S., and K. Aki, Fault planes with barriers: A versatile earthquake model, J. Geophys. Res., $82,5658-5670,1977$.

Ebel, J. E., Source processes of the 1965 New Hebrides Islands earthquakes inferred from teleseismic waveforms, Geophys. J., in press, 1980.

Engdahl, E. R., and C. Kisslinger, Seismologica1 precursors to a magnitude 5 earthquake in the central Aleutian Islands, J. Phys. Earth, 25, 5243-5250, 1977.

Evison, F. F., Fluctuations of seismicity before major earthquakes, Nature, 266, 710-712, 1977a.

Evison, F. F., The precursory earthquake swarm, Phys. Earth P1anet. Int., 15, 19-23, $1977 \mathrm{~b}$.

Evison, F. F., Precursory seismic sequences in New Zealand, N.Z. Journal of Geology and Geophysics, 20, 129-141, 1977c.

Fedotov, S. A., Regularities of the distribution 
of strong earthquakes in Kamchatka, the Kurile islands and northeastern Japan, Trans. Acad. Sci. USSR, Inst. Phys. Earth, 36, (203), 66-93, 1965 (in Russian).

Fuis, G. S. and A. G. Lindh, A change in faultplane orientation between foreshocks and aftershocks of the Galway Lake earthquake, $\mathrm{M}_{\mathrm{L}}=5.2$, 1975, Mojave Desert, California (abstract), Tectonophysics, 52, 601-602, 1979.

Geller, R. J., and C. S. Mueller, Four similar earthquakes in central Calffornia, Geophys. Res. Lett., 7, 821-824, 1980.

Habermann, R. E., Precursory seismicity patterns: Stalking the mature seismic gap, This volume, 1980 .

Hamaguchi, H., and A. Hasegawa, Recurrent occurrence of the earthquakes with similar wave forms and its related problems, J. Seismol. Soc. Japan, 28, 153-169, 1975 (in Japanese).

House, L., and J. Boatwright, Investigation of two high stress-drop earthquakes in the Shumagin seismic gap, Alaska (abstract), EOS, 59, 1124,1978 .

Imamura, A., On the seismic activity of central Japan, Jap. J. Astron. Geophys., 6, 119-137, 1928.

Inouye, $W .$, On the seismicity in the epicentral region and its neighborhood before the Niigata earthquake, Kenshin Jiho, 29, 31-36, 1965 (in Japanese).

Isacks, B. L., and M. Barazangi, Geometry of Benioff zones: Lateral segmentation and downward bending of the subducted 1ithosphere, in Talwani, M. and W. C. Pittman (eds.), Island Arcs, Deep Sea Trenches and Back-Arc Basins, Maurice Ewing Series I, 99-114, 1977.

Ishida, M., and $H$. Kanamori, The foreshock activity of the 1971 San Fernando earthquake, Calffornia, Bul1. Seismo1. Soc. Am., 68, 1265-1279, 1978 .

Ishida, M., and H. Kanamori, Temporal variation of seismicity and spectrum of smal1 earthquakes preceding the 1952 Kern County, California earthquake, Bul1. Seismol. Soc. Am., 70, 509-527, 1980 .

Johnson, C. and L. K. Hutton, The 15 October, 1979 Imperial Valley earthquake: A study of aftershocks and prior seismicity, to appear in the U.S. Geological Survey Professional Paper on the 1979 Imperial Valley Earthquake, 1980.

Jones, L., and P. Molnar, Frequency of foreshocks, Nature, 262, 677-679, 1976.

Jones, L. M., and P. Molnar, Some characteristics of foreshocks and their possible relationship to earthquake prediction and premonitory slip on faults, J. Geophys, Res., 84, 3596-3608, 1979.

Jones, L., Wang Biquan, and Xu Shaoxie, The Haicheng foreshock sequence, This volume, 1980.

Kanamori, H., Use of seismic radiation to infer source parameters, Proc. of Conference III; Fault mechanics and its relation to earthquake prediction, U.S. Geological Survey open-File Report 78-380, p. 283-317, 1978.

Kanamori, $H$. and G. S. Stewart, Seismological aspects of the Guatemala earthquake of February 21,1976 , J. Geophys. Res., 83, 3427-3434, 1978 .

Katsumata, M., and A. Yoshida, Change in seismicity and development of the focal region, Papers in Meteorology and Geophysics, 31, 15-32, 1980.

Keilis-Borok, V. I., L. Knopoff and I. M. Rotvain, Burst of aftershocks, long-term precursors of strong earthquakes, Nature, 283, 259-263, 1980.

Kelleher, J. A., Space-time seismicity of the Alaska-Aleutian seismic zone, J. Geophys. Res., $75,5745-5756,1970$.

Kellieher, J., and J. Savino, Distribution of seismicity before large strike slip and thrusttype earthquakes, J. Geophys. Res., 80, $260-271,1975$.

Kelleher, J., L. Sykes, and J. 0liver, Possible criteria for predicting earthquake locations and their application to major plate boundaries of the Pacific and the Caribbean, J. Geophys. Res., 78, 2547-2585, 1973.

Khattri, I., and M. Wyss, Precursory variation of seismicity rate in the Assam area, India, Geology, 6, 685-688, 1978 .

Kristy, M. J., and D. W. Simpson, Seismicity changes preceding two recent central Asian earthquakes, Submitted to J. Geophys. Res., 1980 .

Lay, T., and H. Kanamori, Earthquake doublets in the Solomon Islands, Phys. Earth Planet. Int., 21, 283-304, 1980a.

Lay, T., and H. Kanamori, An aspertty model of great earthquake sequences, in this volume, $1980 \mathrm{~b}$.

McCann, W., R. S. P. Nishenko, L. R. Sykes, and J. Kraus, Seismic gaps and plate tectonics: Seismic potential for major boundaries, Pageoph., $117,1087-1147,1980$.

McEvilly, T., W. Bakun, and K. Casady, The Parkfield, California earthquake of 1966 , Bu11. Seismol. Soc. Amer., 57, 1221, 1967.

McNa11y, K., Patterns of earthquake clustering preceding moderate earthquakes, central and southern California, abstract, EOS, 58, 1195, 1977 (full text in preprint form).

Meyer, R. P., W. D. Pennington, L. A. Powe11, W. L. Unger, M, Guzman, J. Havskov, S, K. Singh, C. Valdes, and J. Yamamoto, A first report on the Petatlán Guerrero, Mexłco earthquake of 14 March 1979, Geophys. Res. Lett., 7, 97-100, 1980.

Mikumo, T., and T. Miyatake, Earthquake sequences on a frictional fault model with non-uniform strengths and relaxation times, Geophys. J. R. Astron. Soc., 59, 497-522, 1979.

Mitsunami, T., and $\mathrm{K}$. Kubotera, On the activity of the earthquake swarm in the northern part of Aso caldera, 1975 - Interpretation of hypocentral migration, J. Selsmol. Soc. Japan, 30, 73-90, 1977 (in Japanese).

Mizoue, M., M. Nakamura, Y. Ishiketa, and N. Seto, Earthquake prediction from micro-earthquake observation in the vicinity of Wakayama city, 
Northwestern part of the Kii peninsula, central Japan, J. Phys. Earth, 26, 397-416, 1978.

Mogi, K., Some discussions on aftershocks, foreshocks and earthquake swarms - The fracture of a semi-infintte body caused by an inner stress origin and its relation to the earthquake phenomena, Bu11. Earthquake Res. Inst. Tokyo Univ., 41, 615-658, 1963.

Mogi, K., Some features of recent seismic activity in and near Japan, (1), Bu11. Earthquake Res. Inst. Tokyo Univ., 46, 1225-1236, 1968a.

Mogi, K., Source locations of elastic shocks in the fracturing process in rocks (1), Bull. Earthquake Res. Inst. Tokyo Univ., 46, 1103-1125, $1968 \mathrm{~b}$.

Mogi, K., Some features of recent seismic activity in and near Japan, (2) Activity before and after great earthquakes, Bu11. Earthquake Res. Inst. Tokyo Univ., 47, 395-417, 1969.

Mogi, K., Seismic activity and earthquake predictions, in Proceedings of the Symposium on Earthquake Prediction Research, 203-214, 1977 (in Japanese).

Mogi, K., Two kinds of seismic gaps, Pageoph, 117, $1-15,1979$.

Mori, J., Effective stress drops of moderate earthquakes in the eastern Aleutians (abstract), EOS, 61, 294, 1980 .

Nagamune, T., Source regions of great earthquakes, Geophys. Mag., 35, 333-399, 1971.

Nagamune, T., Tectonic structures and multiple earthquakes, Zisin: J. Seismo1. Soc. Japan, 31 , 457-468, 1978 (in Japanese).

Nagumo, S., H. Kobayashi and S. Koresawa, Foreshock phenomena of the 1968 Tokachi-oki earthquake observed by ocean-bottom seismographs off Sanriku, Bull. Earthquake Res. Inst. Tokyo Univ., 46, 1355-1368, 1968 .

Nersesov, I. L., A. A. Lukk, V. S. Ponomarev, T. G. Rautian, B. G. Rulev, A. N. Semonov, and I. G. Simbireva, Possibilities of earthquake prediction, exemplified by the Garm area of the Tadzlink SSR, in Earthquake Precursors, Acad. Sciences, USSG, eds. M. A. Sadovsky, I. I. Nersesov, and L. A. Latynina, 72-99, 1973.

Ohtake, M., Search for precursors of the 1974 IzuHanto-oki earthquake, Japan, Pageoph, 114 , 1083-1093, 1976.

Ohtake, M., T. Matumoto, and G. V. Latham, Seismicity gap near Oaxaca, Southern Mexico as a probable precursor to a large earthquake, Pageoph, 115, 375-385, 1977.

Ohtake, M., T. Matumoto, and G. V. Latham, Patterns of seismicity preceding earthquakes in Central America, Mexico, and California, Proc. Conference Methodology for identifying seismic gaps and soon-to-break gaps, U. S. Geological Survey Open-File Report 78-943, 585-610, 1978.

Ponce, L., K. C. McNally, V. Sumin de Portilla, J. Gonzalez, A. Del Castillo, L. Gonzalez, E. Chael, and M. French, Oaxaca Mexico earthquake of 29 November 1979: A preliminary report on spatio-temporal pattern of preceding seismic activity and main shock relocation, Geofísica Internaciona1, 17, 109-126, 1977-1978.

Santô, T., Shock sequences of the southern Kurile Islands from October 9 to December 31, 1963, Bu11. Int. Inst. Seismol. Earthquake Eng., 1, 33,1964 .

Scholz, C. H. and J. T. Engelder, The role of asperity indention and ploughing in rock friction, I. Asperity creep and stick slip, Int. J. Rock Mech. Min. Sci., 13, 149-154, 1976.

Sekiya, H., Anomalous seismic activity and earthquake prediction, J. Phys. Earth, 25, 585-593, 1977.

Sykes, L. R., Aftershock zones of great earthquakes, seismicity gaps, and earthquake prediction for Alaska and the Aleutians, J. Geophys. Res., 76, 8021-8041, 1971.

Tanaka, K., T. Ohuchi and T. Santô, Formation patterns of seismic gaps before and after great shallow earthquakes, Program and abstracts, Seismol. Soc. Jap. Meeting, No. 1, 24, 1979 (in Japanese).

Tsujiura, M., Spectral features of foreshocks, Bu11. Earthquake Res. Inst. Tokyo Univ., 52 357-371, 1977.

Tsujiura, M., The difference between foreshocks and earthquake swarms, as inferred from the similarity of seismic waveform, Bul1. Earthquake Res. Inst. Tokyo Univ., 54, 309-315, 1979 (in Japanese).

Tsumura, K., A mode1 for temporal variation of seismicity and precursors, abstract of the paper presented at the spring meeting of the Seismological Society of Japan, Tokyo, p. 159, 1979 .

Utsu, T., Seismic activity and seismic observation in Hokkaido in recent years, Rep. Coord. Committee Earthquake Pred., 2, 1-2, 1970 (in Japanese).

Wesson, R. L. and W. L. Ellsworth, Seismicity preceding moderate earthquakes in California, J. Geophys. Res., 78, 8527-8546, 1973.

Wu, Kai-tong, Ming-sheng Yue, Huan-ying Wu, Shinling Chao, Hai-tong Chen, Wei-Qong Huang, Kangyuan Tien and Shou-de Lu, Certain character1stics of the Haicheng earthquake ( $M=7.3$ ) sequence, Chinese Geophysics, 1, 289-308, 1978.

Wyss, M. and J. Brune, The Alaska earthquake of 28 March 1964: A complex multiple rupture, Bu11. Seismol. Soc. Am., 57, 1017-1023, 1967.

Wyss, M. and R. E. Habermann, Seismic quiescence precursory to a past and a future Kurile Island earthquakes, Pageoph, 117, 1195-1211, 1979.

Wyss, M., R. E. Habermann, and A. C. Johnston, Long term precursory seismicity fluctuations, in Methodology for Identifying Seismic Gaps and Soon-to-Break Gaps, Conference VI Nat. Eq. Haz. Red. Prog., 869-894, 1978.

Yamashina, K., and Y. Inoue, A doughnut-shaped pattern of seismic activity preceding the Shimane earthquake of 1978, Nature, 278, 48-50, 1979. 